\title{
Stratigraphy, provenance, and tectonic setting of the Lumsden Dam and Bluestone Quarry formations (Lower Ordovician), Halifax Group, Nova Scotia, Canada
}

\author{
Hayley D. PothieR ${ }^{1,2}$, John W. F. Waldron ${ }^{1 *}$, Chris E. White ${ }^{3}$, S. Andrew Dufrane ${ }^{1}$, and Rebecca A. Jamieson ${ }^{4}$
}

1. Department of Earth \& Atmospheric Sciences, 1-26 Earth Science Building, University of Alberta, Edmonton, Alberta T6G2E3, Canada 2. Current address: Dassuault Systèmes GEOVIA Inc., 110 Yonge Street, Suite 1400, Toronto, Ontario M5C 1T4, Canada 3. Nova Scotia Department of Natural Resources, Halifax, Nova Scotia B3J 2T9, Canada

4. Department of Earth Sciences, Dalhousie University, Halifax, Nova Scotia B3H 4R2, Canada

*Corresponding author $<$ john.waldron@ualberta.ca $>$

Date received: 04 October 2014 Date accepted: 11 January 2015

\begin{abstract}
Cambrian to Ordovician metamorphosed clastic sedimentary rocks of the Meguma terrane have no correlatives elsewhere in Atlantic Canada but are similar to successions in North Wales. In the Meguma terrane, the Cambrian Goldenville Group, dominated by sandstone, is overlain by the Halifax Group, consisting mainly of fine-grained slate and siltstone. Within the Halifax Group widespread Furongian black slate units are overlain by greyer units with rare Early Ordovician fossils, assigned to the laterally equivalent Bear River, Feltzen, Bluestone Quarry, Lumsden Dam and Glen Brook formations. The type section of the Bluestone Quarry Formation, here defined, is on Halifax Peninsula, where four constituent members are recognized; the type section of the Lumsden Dam Formation is here defined in the Lumsden Dam region near Wolfville. Detrital zircons extracted from a sample of the Lumsden Dam Formation show a range of ages similar to those displayed by the underlying Goldenville Group, including abundant Neoproterozoic zircon representing Avalonian or Pan-African sources, and a prominent group of peaks between 1.95 and $2.2 \mathrm{Ga}$, probably representing sources in West Africa. A sample from the Glen Brook Formation east of Halifax shows a similar distribution. In contrast to the correlative Welsh successions, no influx of Mesoproterozoic zircon is seen in Early Ordovician samples, suggesting that, if the two basins were in close proximity in the Cambrian, they had diverged by the Early Ordovician, possibly as a result of strike-slip motion along the margin of Gondwana.
\end{abstract}

\section{RÉSUMÉ}

Les roches sédimentaires clastiques métamorphisées du Cambrien à l'Ordovicien du terrane de Meguma n’ont pas de corrélatif ailleurs au Canada atlantique, mais sont semblables à des successions observées en Galles du Nord. Dans le terrane de Meguma, le groupe de Goldenville du Cambrien, à prédominance de grès, est recouvert du groupe d'Halifax, pour sa part composé principalement de siltite et d’ardoise à grains fins. Au sein du groupe d'Halifax, d'importantes unités d'ardoise noire du Furongien sont recouvertes d'unités plutôt grises et de rares fossiles de l'Ordovicien précoce attribués aux formations latéralement équivalentes de Bear River, de Feltzen, de Bluestone Quarry, de Lumsden Dam et de Glen Brook. Le stratotype de la formation de Bluestone Quarry est ici défini comme se trouvant sur la péninsule d'Halifax, où on reconnaît quatre membres constitutifs, tandis que le stratotype de la formation de Lumsden Dam est ici défini comme se trouvant dans la région de Lumsden Dam, près de Wolfville. Des zircons détritiques extraits d'un échantillon de la formation de Lumsden Dam révèlent différents âges semblables à ceux du groupe de Goldenville sousjacent. On y trouve notamment une abondance de zircon du Néoprotérozoïque représentant des sources avaloniennes ou pan-africaines et un groupe proéminent de pics âgés de 1,95 à 2,2 Ga représentant probablement des sources de l'Afrique de l'Ouest. Un échantillon de la formation de Glen Brook, située à l'est d'Halifax, révèle une distribution semblable. À la différence des successions du Pays de Galles qui y sont liées, aucun afflux de zircon du Mésoprotérozoïque n'est observé dans les échantillons de l'Ordovicien précoce, ce qui tend à indiquer que les deux bassins, qui étaient situés tout près au Cambrien, se sont éloignés à l'Ordovicien précoce, vraisemblablement à la suite d'un mouvement de décrochement le long de la limite de Gondwana.

[Traduit par la redaction] 


\section{INTRODUCTION}

Metamorphosed clastic sedimentary rocks of the Meguma terrane (Fig. 1), the most outboard terrane of the Canadian Appalachians, have no correlatives elsewhere in Atlantic Canada, and their source has been the subject of disagreement. The terrane resided along the northern margin of Gondwana during the Cambrian; however, its exact position along this margin relative to West Africa and Amazonia, and to other peri-Gondwanan terranes, remains uncertain (e.g., Schenk 1997; Waldron et al. 2009).

The Meguma terrane takes its name from a distinctive stratigraphic unit, named the Meguma Series by Woodman (1904) and subsequently termed the Meguma Group (Stevenson 1959) or Supergroup (Schenk 1995a, 1997). It comprises the Cambrian to Early Ordovician Goldenville and Halifax groups (Schenk 1995a; White 2010a), which are overlain by the Silurian to Devonian Rockville Notch
Group (White 2010a, White et al. 2012), all of which are intruded by mainly Late Devonian plutons (Clarke and Halliday 1980). Recent mapping of the Meguma terrane in Nova Scotia has led to the identification and division of several mappable units within the Halifax and Goldenville groups (White 2010b). In this paper we formally define the Lumsden Dam and Bluestone Quarry formations of the upper Halifax Group in the Wolfville and Halifax regions. Although type sections for the remaining units have yet to be defined, they have been named as formations, and to avoid confusion we here follow the suggestion of a reviewer and the journal editors and use formal nomenclature (e.g., Cunard Formation) for all of these units pending future formal definition of type sections. Both the Lumsden Dam and Bluestone Quarry formations record similar sedimentological features, and the presence of a mass transport deposit in the Bluestone Quarry Formation suggests they were deposited in a slope environment. Here we also pres-

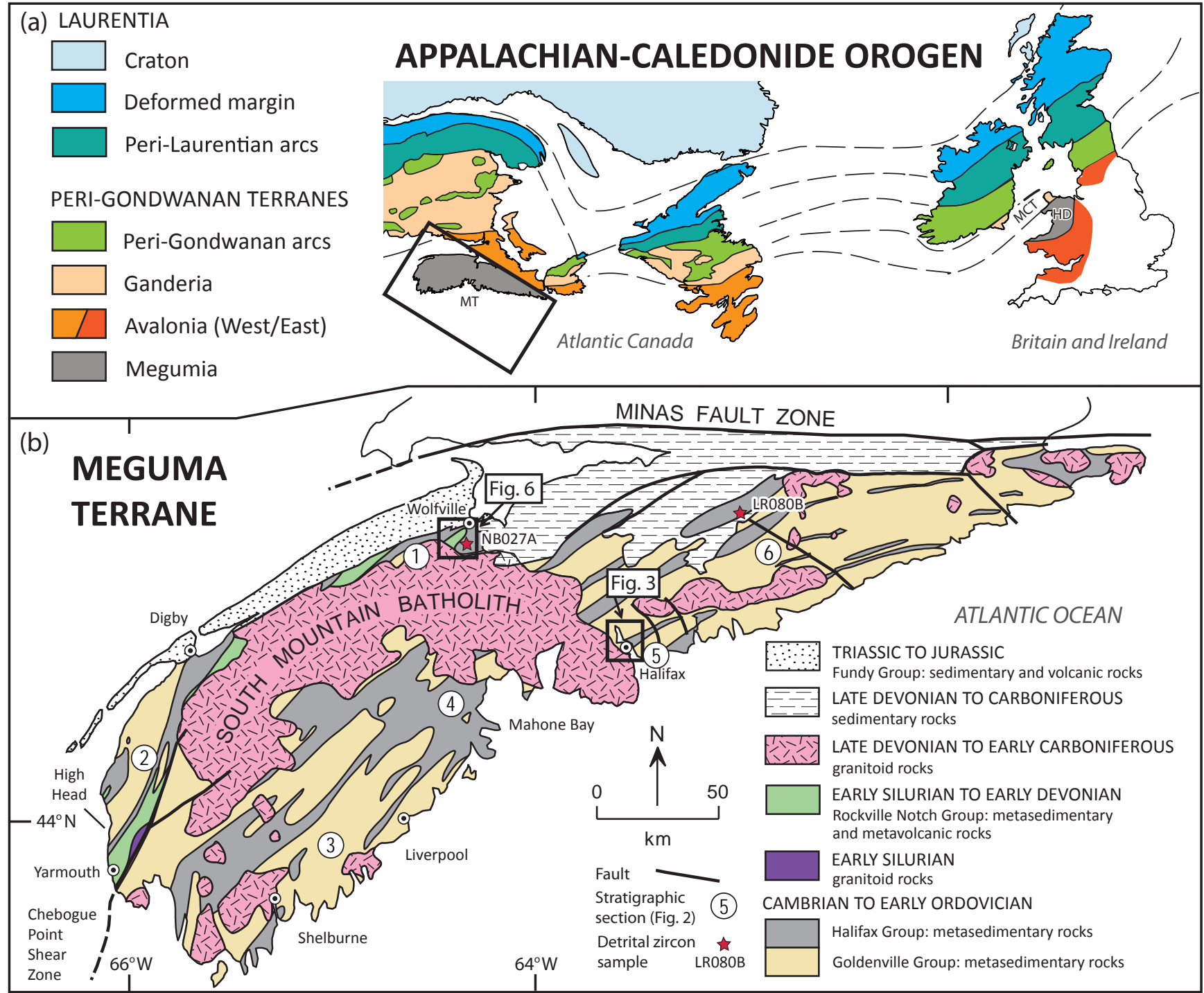

Figure 1. Meguma terrane (after White 2010b) with inset map showing its location in the northern Appalachian-Caledonide orogen (after Hibbard et al. 2006). Boxes show location of maps shown in Figs. 3 and 6. Numbers refer to stratigraphic columns shown in Fig. 2. Abbreviations: HD - Harlech Dome; MCT - Monian composite terrane; MT - Meguma terrane. 
ent the first detrital zircon data from the Halifax Group, which complement previous provenance studies conducted in the Goldenville and Rockville Notch groups (Krogh and Keppie 1990; Murphy et al. 2004b; Waldron et al. 2009) and in correlative units in the British Isles (Pothier et al. 2014). The data show similar distributions to underlying units, and are consistent with a primary West African source region with a minor input of Amazonian detritus.

\section{GEOLOGIC SETTING}

\section{Meguma terrane}

The Meguma terrane is exposed south of the Minas Fault Zone in Nova Scotia (Fig. 1). The thick ( $>13 \mathrm{~km}$ ) CambrianOrdovician variably metamorphosed sandstone-shale succession of the Goldenville and Halifax groups is overlain unconformably by Silurian-Devonian volcanicsedimentary rocks of the Rockville Notch Group (White et al. 2012). This succession has been deformed into SW-NE trending folds during the Middle Devonian Neoacadian orogeny (van Staal 2007; White et al. 2007), and were intruded by the South Mountain Batholith and other plutons during the Late Devonian (Clarke and Halliday 1980). Regional metamorphism is greenschist facies (chlorite-biotite zones) with low-pressure amphibolite facies (andalusitestaurolite-cordierite zones) in southwestern and eastern mainland Nova Scotia (Keppie and Muecke 1979; Raeside and Jamieson 1992). Low-pressure (andalusite-cordierite$\mathrm{K}$-feldspar zones) contact metamorphism is present within ca. $2 \mathrm{~km}$ of the contact with the South Mountain Batholith and numerous smaller plutons (Jamieson et al. 2012). Unconformably overlying the Meguma terrane and adjacent Avalonia are the Late Devonian to Carboniferous successions of the Maritimes Basin and the Mid-Triassic to Early Jurassic Fundy Group (Klein 1962; Martel and McGregor 1993).

The Chebogue Point Shear Zone (CPSZ) is located in southwestern Nova Scotia in the Yarmouth region (Fig. 1). It strikes N-S to NE-SW (White 2010b) and is assumed to pass into the South Mountain Batholith, although has not been clearly traced east of its intersection with the batholith. White (2010b) has described the CPSZ as a tectonostratigraphic boundary, dividing the Meguma Supergroup into different, though correlative, units at the formation level, lying to the northwest and southeast of the shear zone and South Mountain Batholith.

Basement characteristics such as age, deformation, and composition normally provide critical information about a terrane's origin; however, Meguma terrane basement rocks are not exposed anywhere in Nova Scotia. Sm-Nd isotopic studies on Meguma granitoid rocks (Clarke et al. 1988) and basement xenoliths (Eberz et al. 1991) indicate that the deeper crust includes material with a younger residence age than the overlying Meguma Supergroup. Greenough et al. (1999) dated zircon and monazite from basement xe- noliths, which showed a Pan-African - Avalonian population (575-630 Ma), with a possible Mesoproterozoic grain population defined by the upper intercepts of a discordant zircon fraction. These data were interpreted by Greenough et al. (1999) to suggest that the Meguma succession rests upon a basement with Avalonian affinities. It has been proposed that the West Avalonia and the Meguma terrane once formed a part of the same microcontinent and that the Meguma succession was deposited on Avalonian crust (e.g., Keppie et al. 1997; Landing 2004; Murphy et al. 2004a; Linnemann et al. 2012). Others interpret the contact between the two terranes as a thrust (e.g., Eberz et al. 1991; Keppie and Dallmeyer 1987; Waldron et al. 1989; Greenough et al. 1999) along which the Meguma terrane was emplaced over Avalonia.

\section{Goldenville Group}

The Goldenville Group (Fig. 2) is the oldest unit in the Meguma terrane, and spans the early Cambrian (Terreneuvian) to the early Furongian (White et al. 2012). It is primarily composed of thick-bedded metamorphosed sandrich turbidites with local interbedded siltstone and slate (Harris and Schenk 1976; Waldron and Jensen 1985) with an estimated thickness of $\geq 8000 \mathrm{~m}$ (White et al. 2012). The highest part of the Goldenville Group is characterized by manganese-rich slate and siltstone (e.g., Waldron 1992). In southwestern Nova Scotia, the High Head member (Fig. 2) contains abundant trace fossils, including Oldhamia, that are characteristic of the early Cambrian (Gingras et al. 2011). These fossils are consistent with detrital zircon collected from the Church Point Formation (Fig. 2) that suggested a maximum depositional age close to the EdiacaranTerreneuvian boundary (Waldron et al. 2009). In southern Nova Scotia, the Government Point Formation (Fig. 2) yielded a middle Cambrian (Epoch 3) Acado-Baltic trilobite faunule (Pratt and Waldron 1991).

\section{Halifax Group}

The Halifax Group spans the Furongian to Lower Ordovician (Fig. 2) and is generally much finer grained than the underlying Goldenville Group (White et al. 2012). The lowest unit in the Halifax Group as defined by White (2010b) is the Cunard Formation in the Halifax region and its correlatives, the Acacia Brook and North Alton formations in the Digby-Yarmouth and Wolfville regions (Fig. 2, 3a). These units are strongly cleaved, dark grey to black slate, with thin lenses and beds of metamorphosed siltstone and fine- to medium-grained sandstone. They contain abundant sulphide minerals (dominantly pyrrhotite) and weather rusty brown. An acritarch assemblage sampled from the North Alton Formation indicates a Jiangshanian (mid-Furongian) age (White et al. 2012). Conformably above these units are the regionally correlative Lumsden Dam, Bluestone Quar- 


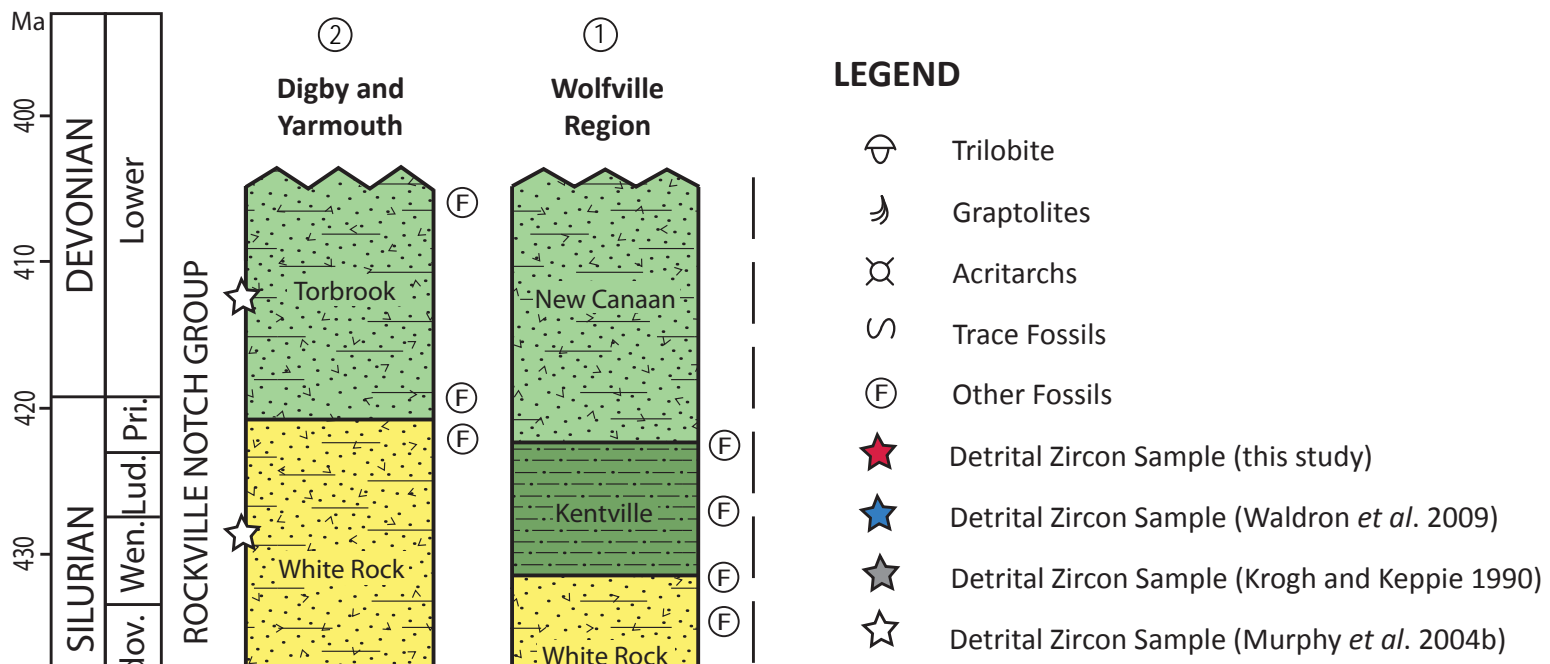

Protolith lithology

Coarse Sandstone

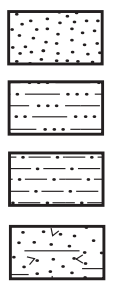

Sandstone

Siltstone

Mudstone

Interlayered Sedimentary and Volcanic Rock
(3)

Southwest Shore

0
$y$
0
(4)

Mahone Bay

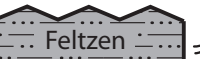

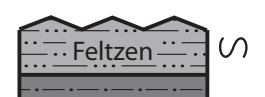

-

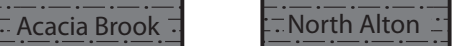

Acacia Brook

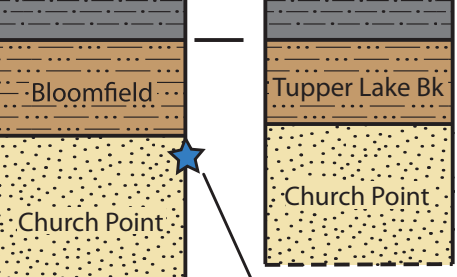

$\mathrm{U}-\mathrm{Pb}$ detrital age $(<529 \pm 19 \mathrm{Ma})$

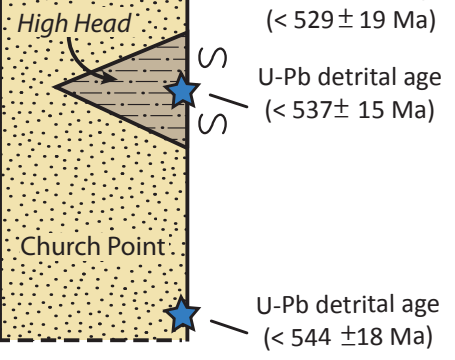

Ediacaran

(<544 $\pm 18 \mathrm{Ma})$
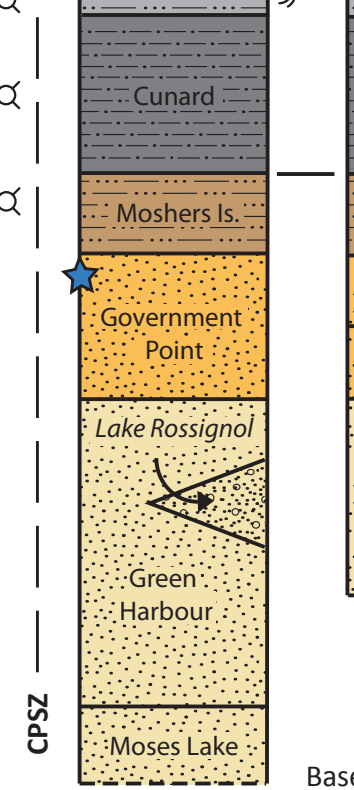

(5) GROUP

Formation

Member

(5)

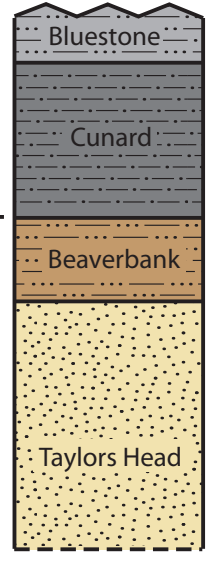

Base of Goldenville Group not exposed

(6)

Typefaces indicate hierarchy of lithostratigraphic units

Eastern

LR080B Shore

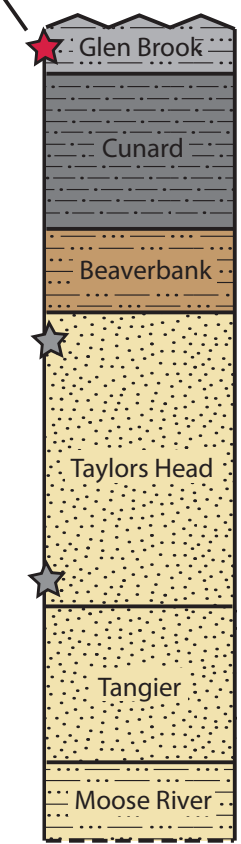

Figure 2. Generalized stratigraphy of the Meguma terrane in different regions in Nova Scotia (after O'Brien 1988; Horne and Pelly 2007; White 2010b; White et al. 2012) showing the locations sampled in detrital zircon studies. Paleontological and $\mathrm{U}-\mathrm{Pb}$ age data are from sources described in the text. Time scale of Peng et al. (2012). 


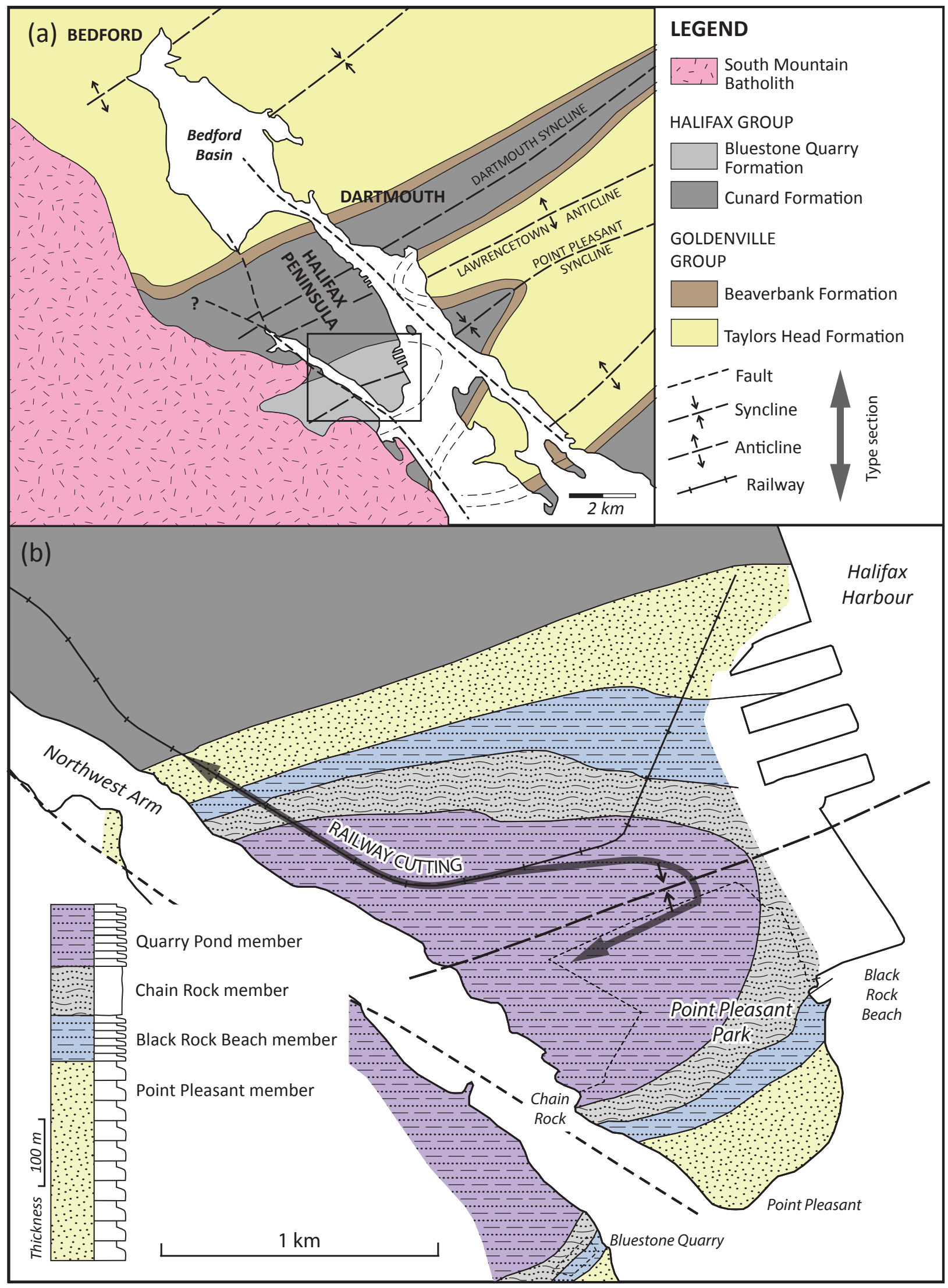

Figure 3. Geological map of (a) the Halifax area after White et al. (2008) and (b) the Bluestone Quarry Formation (after Jamieson et al. 2011). 
ry, Glen Brook, Feltzen, and Bear River formations (Fig. 2). These formations, which are the focus of the remainder of the paper, comprise light to dark grey slate interlayered with cross-laminated siltstone and fine-grained sandstone. They contain noticeably less pyrrhotite, pyrite, and arsenopyrite than the underlying formations. Tremadocian graptolite fossils are preserved in the Bear River, Feltzen, and Lumsden Dam formations (White 2010a).

The uppermost units of the Halifax Group are preserved only in the Wolfville area. The Elderkin Brook Formation (Fig. 2) conformably overlies the Lumsden Dam Formation. It consists of diffusely to finely laminated, cleaved mudstone. Unlike the Lumsden Dam Formation this unit lacks cross-laminated siltstone and sandstone beds, but is mildly bioturbated. Its colour ranges from pale greenish grey to medium grey, and it weathers to a purple-red colour in places. Acritarch and trace fossils in this unit indicate late Tremadocian age (White et al. 2012). The overlying Hellgate Falls Formation (Fig. 2; White 2010a), is light to dark grey slate interbedded with light to dark grey thin siltstone and sandstone beds and lenses. Abundant bioturbation textures and trace fossils characterize this unit. Locally, black slate occurs at the very top of the formation (White 2010a). It is disconformably overlain by the Silurian White Rock Formation (White 2010a). The age of the Hellgate Falls Formation is constrained by Early Ordovician acritarch fossils, which range from the latest Tremadocian to Floian (White et al. 2012).

\section{Rockville Notch Group}

The Silurian to Lower Devonian Rockville Notch Group (formerly the Annapolis Supergroup of Schenk 1995b) is preserved on the northwest side of the CPSZ and South Mountain Batholith (Fig. 2). The basal White Rock Formation, which rests unconformably over the Halifax Group (White 2010a), comprises shallow marine metamorphosed sedimentary (Lane 1975; Bouyx et al. 1997) and rift-related volcanic rocks (Schenk 1997; Keppie and Krogh 1999; MacDonald et al. 2002). A rhyolite near its base produced an early Llandovery $\mathrm{U}-\mathrm{Pb}$ zircon age of $442 \pm 4 \mathrm{Ma}$ (Keppie and Krogh 2000) and a felsic tuff higher in the formation in the Yarmouth area produced a mid-Llandovery age of 438 $\pm 3 \mathrm{Ma}$ (MacDonald et al. 2002). The White Rock Formation is overlain by siltstone and slate of the Kentville Formation (Smitheringale 1960; Taylor 1965). The Kentville Formation contains graptolites and microfossils (Smitheringale 1973; Bouyx et al. 1997) indicative of a late Wenlock to early Pridoli (Silurian) age. The Kentville Formation is overlain by Pridoli to upper Lower Devonian (Smitheringale 1973; Bouyx et al. 1997) marine sedimentary and volcanic rocks of the New Canaan and Torbrook formations (Smitheringale 1960; Taylor 1965).

\section{FORMAL DESCRIPTIONS}

White (2010b) has provided a review of the informal stratigraphic subdivisions within the Goldenville and Halifax groups established during mapping in the Meguma terrane. Herein, we formally define two of the regionally correlative units in the upper part of the group, the Bluestone Quarry and Lumsden Dam formations and present more detailed descriptions of these formations to better define the environment of deposition and regional tectonic significance of the sedimentary rocks in the upper part of the Halifax Group. All coordinates are based on the Universal Transverse Mercator (UTM) projection, using North American Datum 1983.

\section{Bluestone Quarry Formation}

The Bluestone Quarry Formation is mappable in the Halifax area where it is exposed in the core of a SW-plunging syncline in Point Pleasant Park, in an adjacent railway cut, and in numerous other exposures on both sides of Northwest Arm (Fig. 3). It was recognized as a distinctive unit (Bluestone member of the Halifax Formation) by Jamieson et al. (2005), and named Bluestone Formation by White et al. (2008); the unit is here named Bluestone Quarry Formation to avoid confusion with a similarly named unit in West Virginia, USA (Cardwell et al. 1968). The name is derived from a quarry located immediately SW of Northwest Arm (Jamieson et al. 2012), the source of a common building stone in the Halifax area. The unit conformably overlies graphitic, sulphide-rich slate and hornfels of the Cunard Formation. The rocks of the Bluestone Quarry Formation are interbedded light grey to beige sandstone and siltstone with medium to dark grey slate, variably overprinted by contact metamorphism. Bedding is continuous at the outcrop scale (several metres). Beds are graded and have sharp, flat bases, with scour structures in places. Sandstone commonly appears massive to parallel or cross-laminated; siltstone is most often cross-laminated, and slate exhibits weak parallel to wavy laminae. The cross-laminae show unidirectional current flow, typically with a northward component, and the ripples have sinuous crest morphologies. Trough cross-laminations and climbing-ripple cross-laminations are common (Fig. 4).

The Bluestone Quarry Formation lacks the abundant sulphide minerals present in the underlying Cunard Formation. It contains carbonate concretions that have locally been metamorphosed to calc-silicate rock (Jamieson et al. $2005,2012)$. The concretions, which are broadly parallel to, but overprint bedding, typically lie within the upper parts of siltstone and sandstone beds; this association helps to distinguish this unit from the underlying Cunard Formation. Much of the Bluestone Quarry Formation lies within the contact aureole of the South Mountain Batholith (Halifax Pluton), where the regional chlorite zone assemblage is 

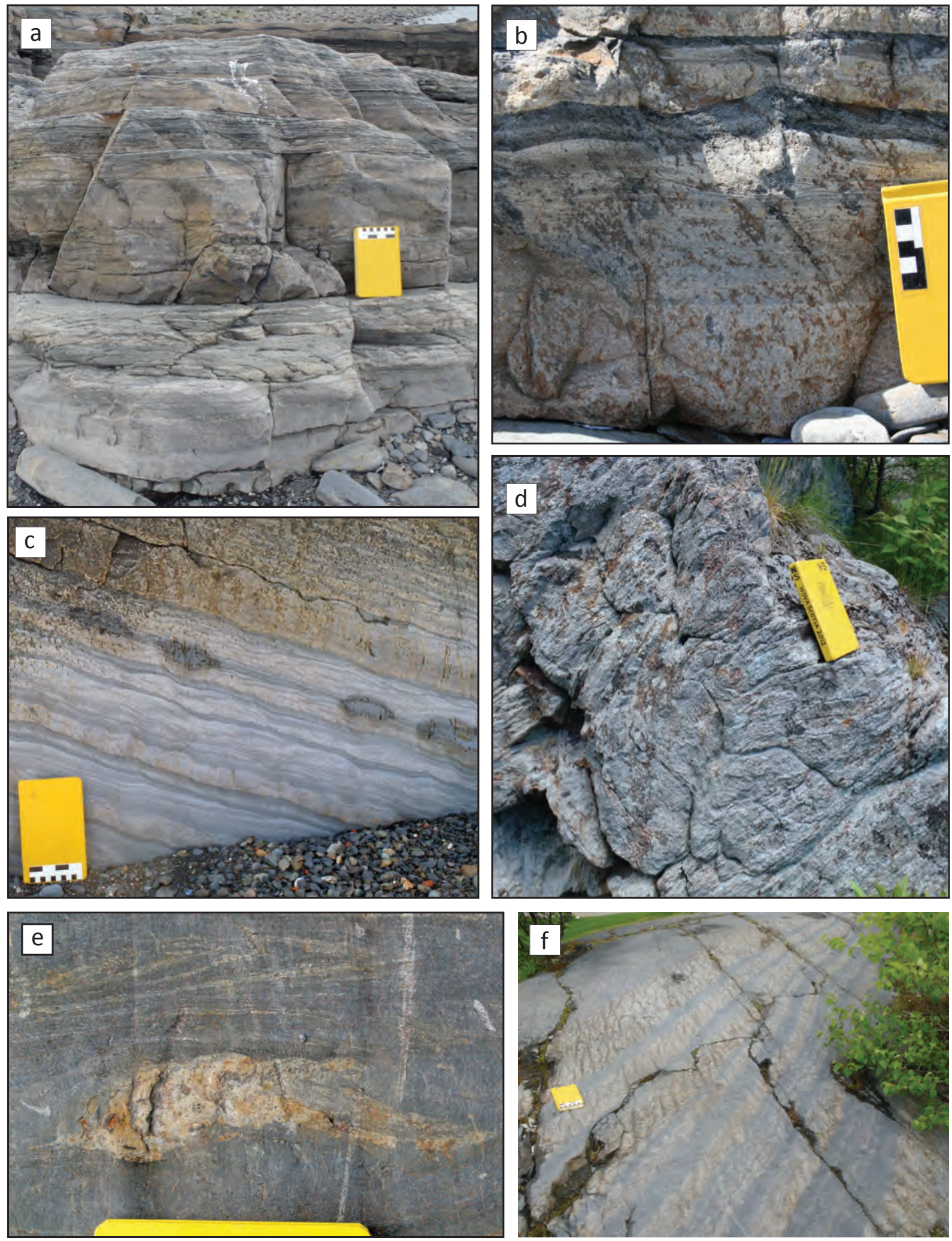

Figure 4. Typical field appearances of the Bluestone Quarry Formation: (a-b) Point Pleasant member, showing thick sandstone beds with well developed Bouma "B" divisions of parallel-laminated sandstone; (c) Black Rock Beach member showing abundant thinly bedded siltstone and sandstone beds with ripple cross-laminations; bed in middle of view shows four oval carbonate-bearing concretions; (d) Chain Rock member showing folded bedding; (e) Chain Rock member showing isolated sandstone lens; (f) Quarry Pond member showing thinly bedded graded siltstone; climbing ripple cross-lamination is distorted by tectonic deformation and emphasized by differentiated cleavage. 
overprinted by the assemblage cordierite + biotite \pm andalusite, and the slaty cleavage is annealed within ca. $1 \mathrm{~km}$ of the contact (Jamieson et al. 2012). Compositional differences from the adjacent Cunard Formation produce distinctive metamorphic mineral assemblages and isograds within the Bluestone Quarry Formation, which have proven useful in mapping the boundary (Jamieson et al. 2005; Jamieson et al. 2012).

The type section for the Bluestone Quarry Formation is located along the railway cutting and in adjacent Point Pleasant Park (Fig. 3), where the formation outcrops almost in its entirety. The Bluestone Quarry Formation is here divided into four informal members: the Point Pleasant member, the Black Rock Beach member, the Chain Rock member, and the Quarry Pond member (Fig. 3; following Jamieson et al. 2011). The basal contact of the formation (Fig. 5), exposed in the railway cutting [20T 453021E $4942263 \mathrm{~N}$ ], is conformable and is defined within a gradational transition at the lowest occurrence of fine-grained metamorphosed sandstone beds (Point Pleasant member) with carbonate concretions (Fig. 5). The highest part of the section (Quarry Pond member) in the type area occurs in the core of the Point Pleasant syncline. No overlying strata other than Quaternary deposits are observed in the Halifax region, where the Bluestone Quarry Formation is the youngest exposed bedrock unit; thus an upper stratigraphic contact cannot be defined. The minimum thickness of the Bluestone Quarry Formation is estimated to be $531 \mathrm{~m}$. Additional descriptions are provided in a companion paper which focusses on the interpretation of the Chain Rock member (Waldron et al. 2015).

The lowest, Point Pleasant member (approximately 295 $\mathrm{m}$ thick) is well exposed inland and along the shoreline in the south end of Point Pleasant Park (Fig. 3). It comprises thinly to thickly bedded (bed-thickness terminology after Boggs 2001) high-energy turbidite deposits and is the most sand-rich member (Figs. 4a, b). Bouma divisions A through to $\mathrm{E}$ are common, but partial Bouma sequences are also present, where the basal divisions are missing or just divisions $\mathrm{A}$ and $\mathrm{E}$ are preserved. The interbedded slates are distinctly darker, and more graphitic than in the higher parts of the formation.

The Black Rock Beach member is $\sim 68 \mathrm{~m}$ thick and is best exposed at Black Rock Beach (Fig. 3). The member contains very thin- to medium-bedded low energy turbidite deposits (Figs. 4c, 5). Bouma divisions $\mathrm{C}-\mathrm{E}$ and $\mathrm{D}-\mathrm{E}$ are common, but Bouma A divisions are absent.

The Chain Rock member is $\sim 75 \mathrm{~m}$ thick and is more resistant to erosion than the other members, forming a high ridge within Point Pleasant Park (Fig. 3). It is characterized by bedding that is variably folded, discontinuous, or completely disordered, with isolated blocks of siltstone and sandstone within a featureless matrix (Fig. 4d, e), described in more detail in a companion paper (Waldron et al. 2015). The deformation and disruption of bedding pre-dated the development of the regional slaty cleavage, but post-dated the formation of the carbonate concretions (Jamieson et al. 2011). On the east coast of the Northwest Arm, and in the region of Bluestone Quarries to the west, the contact with the underlying Black Rock Beach member is visible [20T $445499 \mathrm{E} 4940918 \mathrm{~N}]$. The sharp contact appears to be an erosional surface where the Chain Rock member incises into the underlying unit. Due to the stratiform geometry and chaotic deformational style of the Chain Rock member it is interpreted as a downslope mass-transport deposit (Jamieson et al. 2011; Waldron et al. 2015).

The Quarry Pond member has a minimum thickness of $93 \mathrm{~m}$. It is best exposed in the railway cutting (Fig. 3) and also forms scattered outcrops within Point Pleasant Park and in adjacent residential subdivisions. This member is very similar to the Black Rock Beach member as it also consists of very thin- to medium-bedded, low-energy turbidite deposits in which Bouma divisions $\mathrm{C}-\mathrm{E}$ and $\mathrm{D}-\mathrm{E}$ are common (Fig. 4f). The Quarry Pond member is the highest unit in the formation and occupies the core of the Point Pleasant syncline; its original top is not exposed, but it is unconformably overlain by unconsolidated Quaternary sediments.

The age of the Bluestone Quarry Formation is not well constrained, as no body fossils have been found in this area (White et al. 2008). A single occurrence of deformed burrows was reported by Hart (2006). Based on its stratigraphic position above the Cunard Formation, the Bluestone Quarry Formation has been correlated with the unfossiliferous Glen Brook Formation (Fig. 2), and with the Lumsden Dam, Feltzen, and Bear River formations, which contain graptolite and acritarch fossils of Tremadocian age (White et al. 2012). This provides the best estimate for the age of the Bluestone Quarry Formation, assuming the contacts are not diachronous.

\section{Lumsden Dam Formation}

The divisions of the Halifax Group in the Wolfville region, including the Lumsden Dam Formation, were first described and informally named by White (2010b). In the Wolfville region, the Lumsden Dam Formation is exposed on the northwest limb of an anticline (Fig. 6). Excellent exposure of the unit can be seen in the Black River area, the best exposures being in an overflow channel located to the northwest of Lumsden Dam. This section has roughly 200 $\mathrm{m}$ of continuous outcrop (Fig. 7). The continuous outcrop terminates southward at the south end of the channel cut [20T 389943E 986789N]; to the north it disappears under vegetative cover [20T 389878E 4986982N]. Sedimentary structures were difficult to observe along the cliff edge of the channel, but were easily seen on adjacent areas of flat exposure (Fig. 8, 9). The remainder of the type section is defined in intermittent exposure to the north and south of this well exposed section.

The Lumsden Dam Formation consists mainly of metamorphosed light grey siltstone and dark grey mudstone 


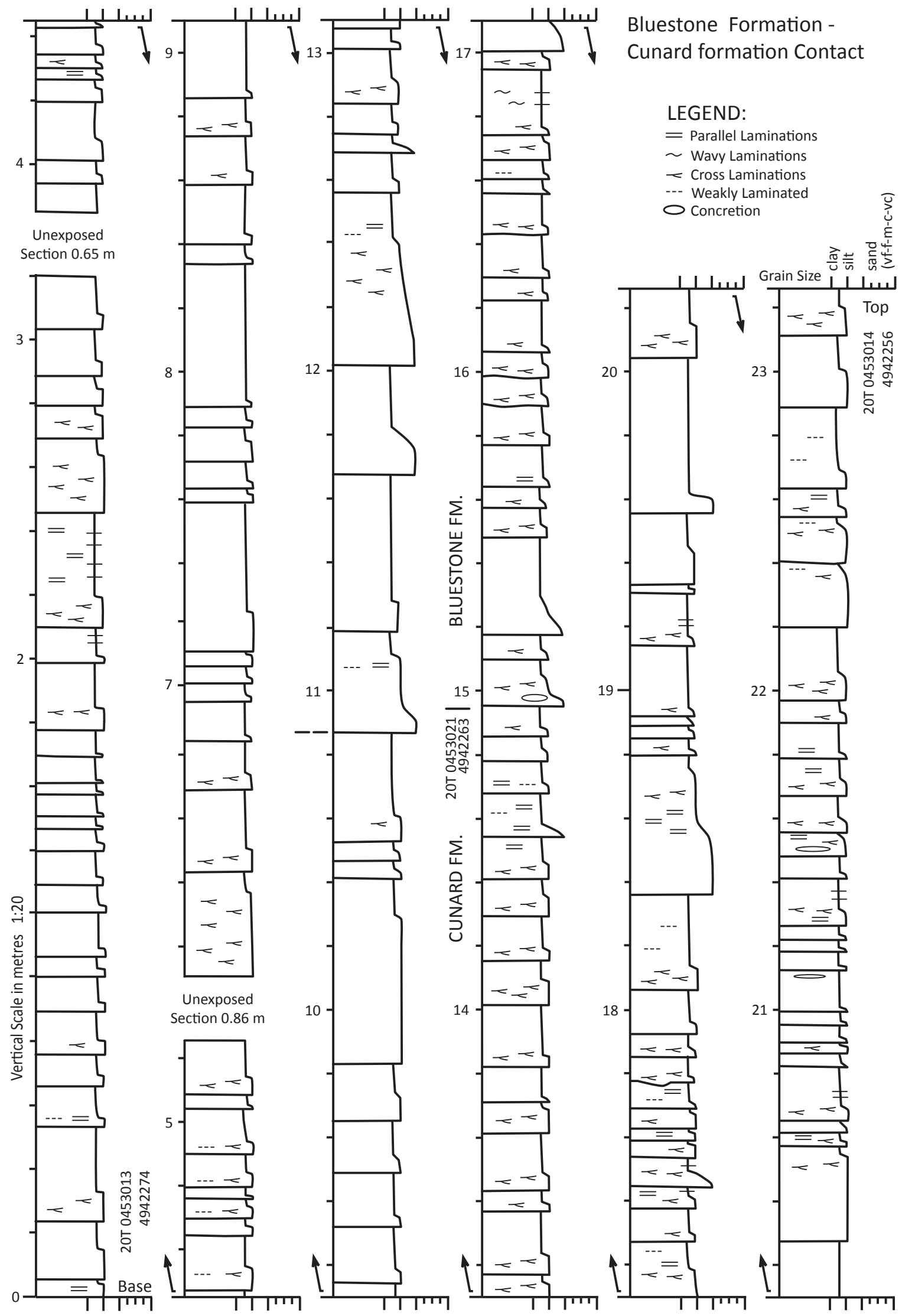

Figure 5. Detailed section of the contact between the Cunard and Bluestone Quarry formations. 


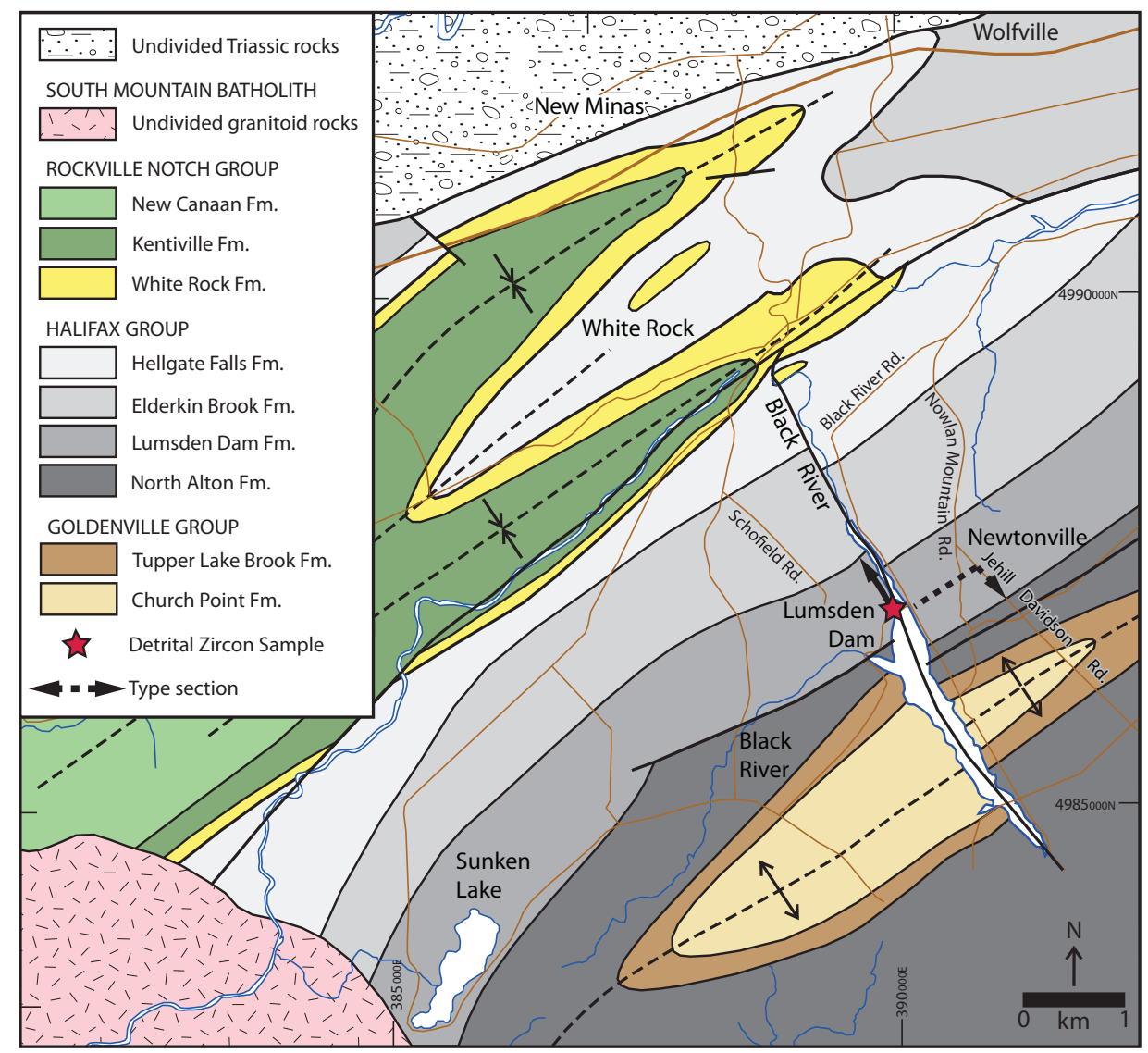

Figure 6. Geological map of the Wolfville area (after White 2010a).

with minor very fine-grained sandstone (Fig. 9). Graded beds are prevalent throughout the section and are very thin $(1-3 \mathrm{~cm})$ to medium $(10-30 \mathrm{~cm})$ bedded. Siltstone and sandstone beds are parallel laminated to cross-laminated, while most mudstone layers contain thin parallel laminae of silstone. Thicker siltstone and sandstone beds are laterally continuous at the outcrop scale (several metres), but thin (less than $2 \mathrm{~cm}$ ) cross-laminated beds commonly appear as lenses or as semi-continuous and lenticular (Fig. 9c). Bed bases are sharp and flat with some scouring.

The Lumsden Dam Formation contains minor sulphide minerals (noticeably less than the underlying North Alton Formation) and it weathers to rusty brown. Rare, small (1-3 $\mathrm{cm})$ carbonate concretions are also found within the siltstone and sandstone beds. The section contains four mafic intrusions that were emplaced parallel to bedding. These fine-grained, medium grey sills range in thickness from 90 to $120 \mathrm{~cm}$ and are easily confused with thick sandstone beds, as they are similar in field appearance to the coarser units of the host Lumsden Dam Formation (Figs. 7, 9d).

The boundary between the Lumsden Dam Formation and the underlying North Alton Formation is located along Jehill Davidson Road in Newtonville (Fig. 6). Intermittent exposure along the roadbed shows a change from dominantly medium grey to black mudstone with locally abundant sulphides and siltstone beds less than $10 \mathrm{~cm}$ thick in the North Alton Formation, up into dominantly medium grey to greenish-grey mudstone with siltstone and sandstone beds that reach thicknesses greater than $10 \mathrm{~cm}$ in the Lumsden Dam Formation. The boundary is placed at the lowest occurrence of a siltstone bed with thickness greater than $10 \mathrm{~cm}$ [20T 391089E $4986980 \mathrm{~N}$ ]. White et al. (2012) have described the contact as gradational over an interval of $5 \mathrm{~m}$ in continuous exposure revealed temporarily during the draining of Lumsden Lake, and in other parts of the region.

The boundary between the Lumsden Dam Formation and the overlying Elderkin Brook Formation is not visible along the east side of Black River Road, but is constrained within $62 \mathrm{~m}$ between coordinates 20T 389838E 4987401N and $20 \mathrm{~T} 389815 \mathrm{E} 4987459 \mathrm{~N}$. Here there is a transition from the Lumsden Dam Formation, which contains siltstone and thick cross-laminated sandstone, into thick laminated mudstone with only minor siltstone of the Elderkin Brook Formation (Fig. 9e). The boundary is placed at the highest occurrence of a siltstone bed thicker than $2 \mathrm{~cm}$. In the studied area the Lumsden Dam Formation is estimated to be $550 \mathrm{~m}$ thick, although White (2010a) suggested it could reach up to $1500 \mathrm{~m}$ thick in some areas.

The graptolite Rhabdinopora flabelliformis flabelliformis has been identified (White et al. 2012) in beds near the middle of the Lumsden Dam Formation (Fig. 9b), and acritarch assemblages restrict the age of the Lumsden Dam Formation to the early to middle Tremadocian (White et 

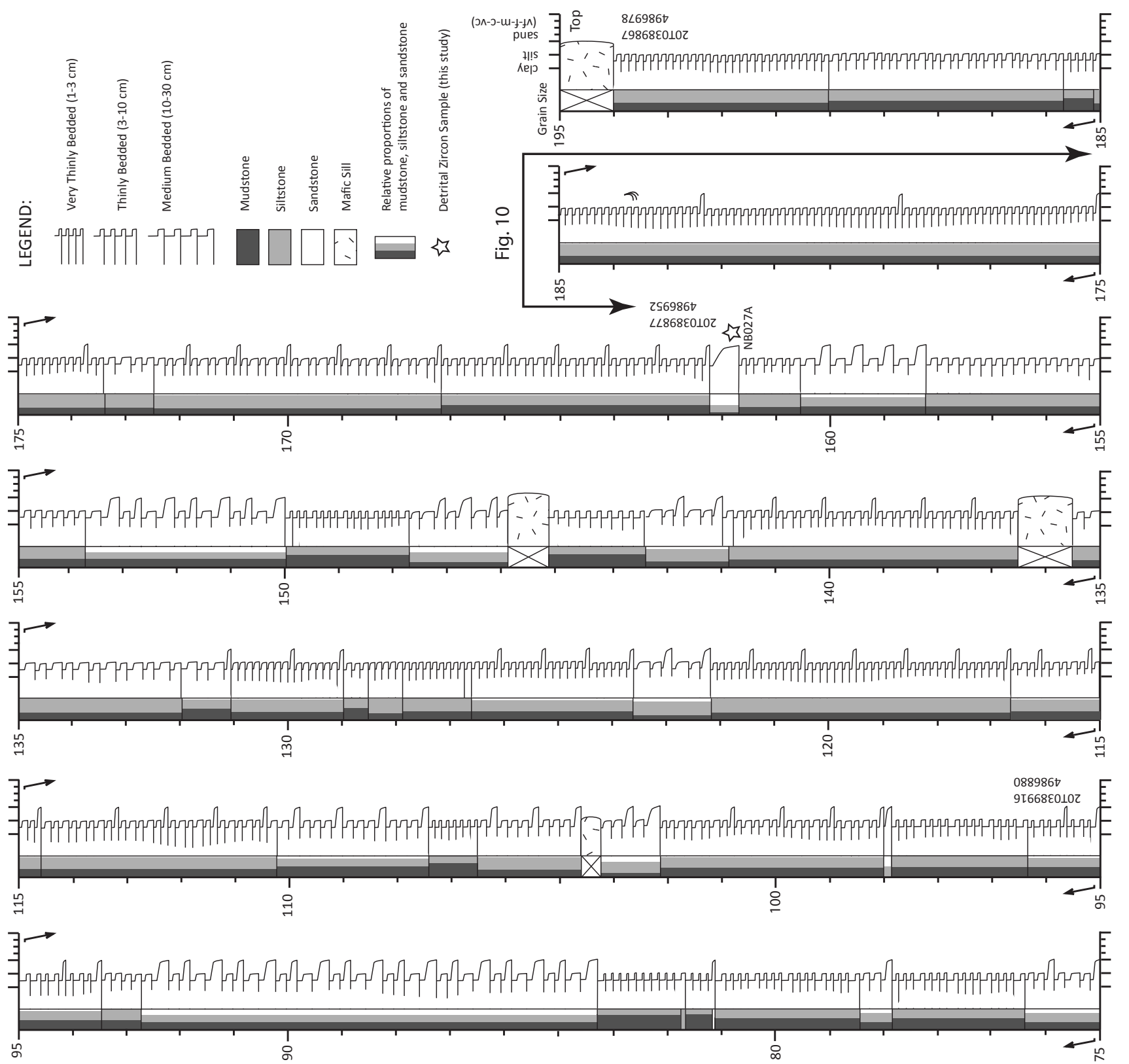


\section{Lumsden Dam Formation Detailed Section}

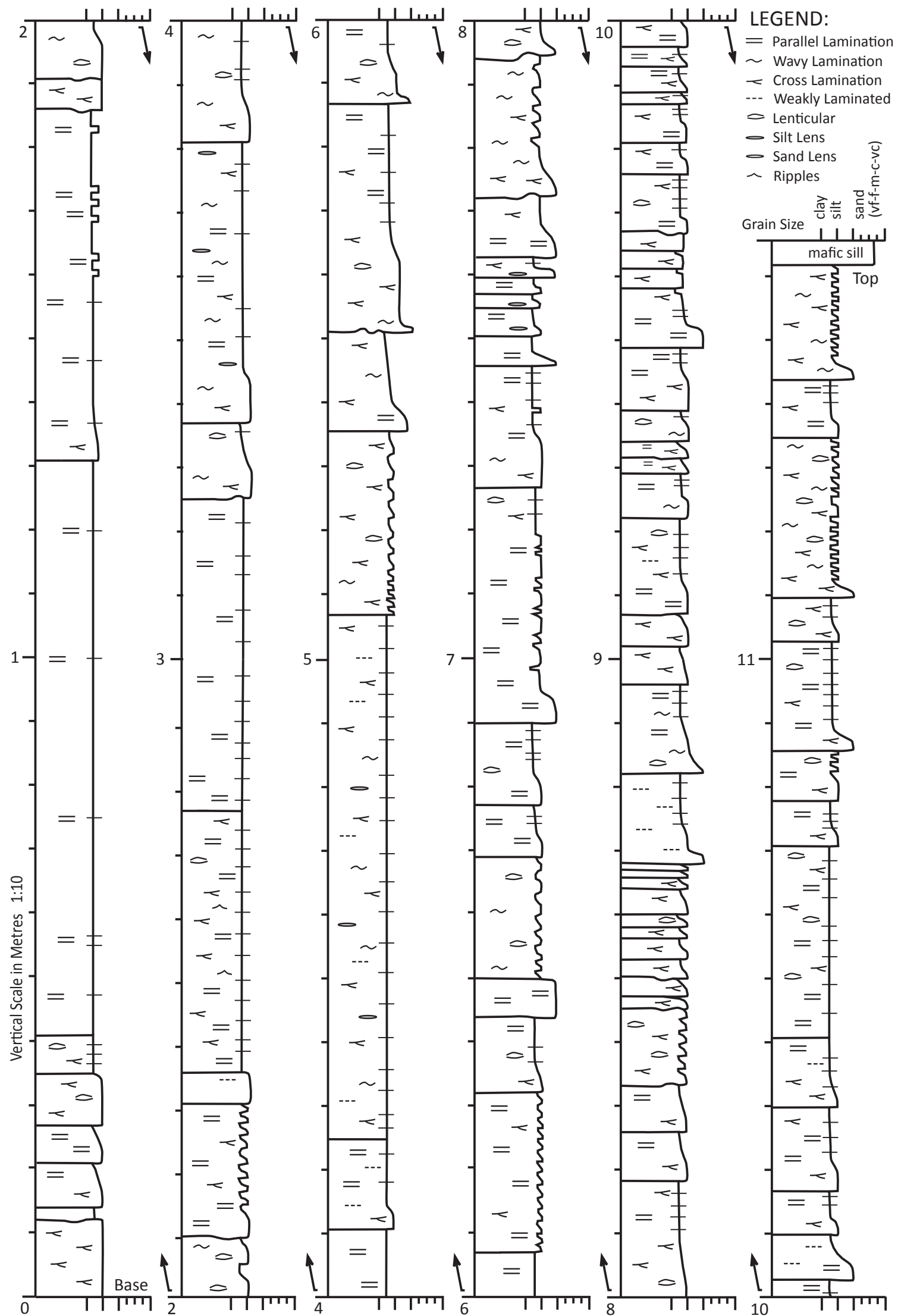

Figure 8. Detailed section representative of the Lumsden Dam Formation. 

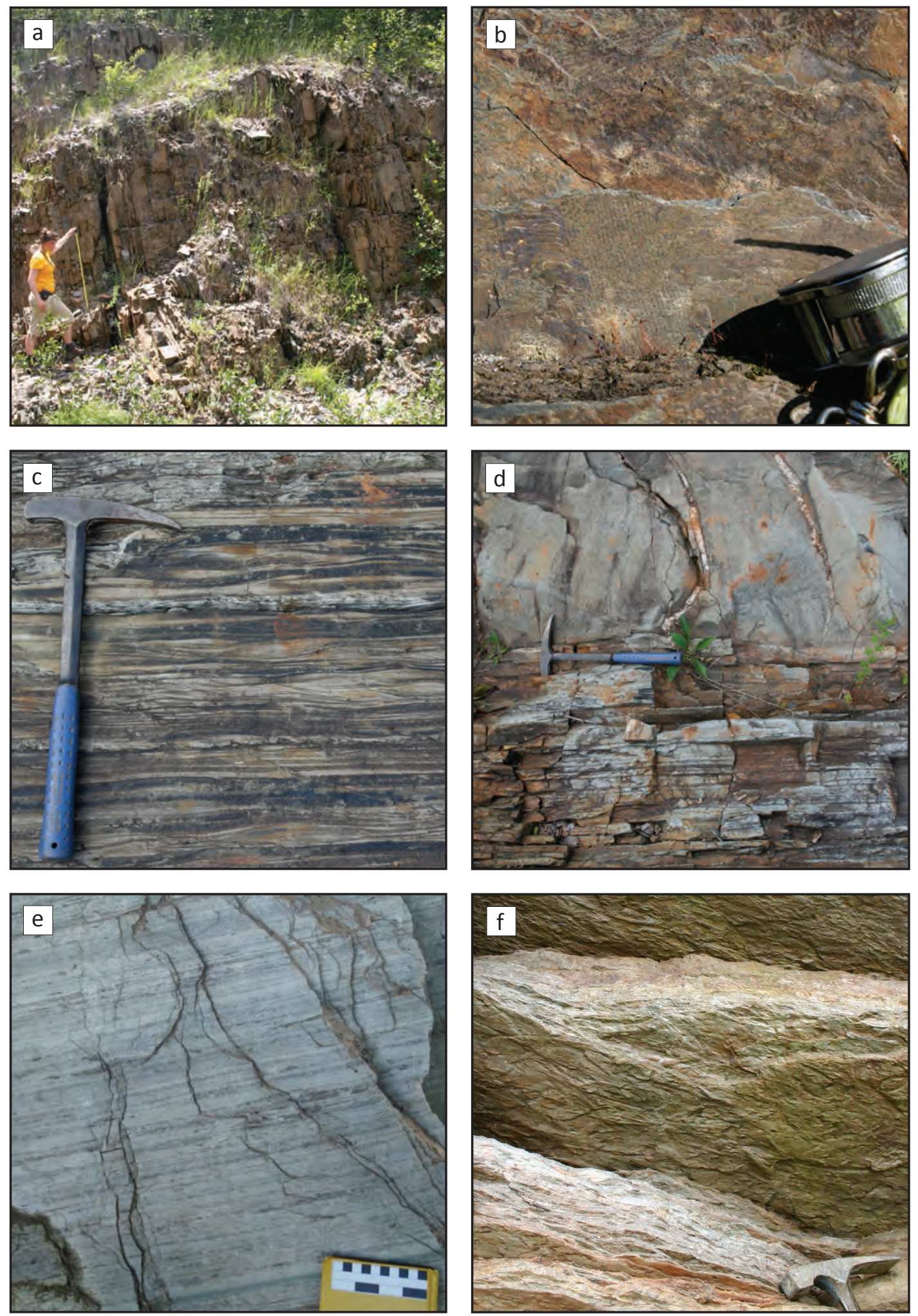

Figure 9. Typical field appearance of units in the Wolfville area: (a) Lumsden Dam Formation general view; (b) graptolite fossil in Lumsden Dam Formation, exposed on bedding surface to left of hand lens; (c) thinly interbedded siltstone and mudstone of the Lumsden Dam Formation displaying ripple cross-lamination; (d) Lumsden Dam Formation in contact with a Type I mafic sill (contact below pick of hammer); (e) finely laminated mudstone of the Elderkin Brook Formation; and (f) interbedded siltstone and mudstone of the Hellgate Falls Formation showing bioturbation structures on basal overhanging surface of bed above hammer. 


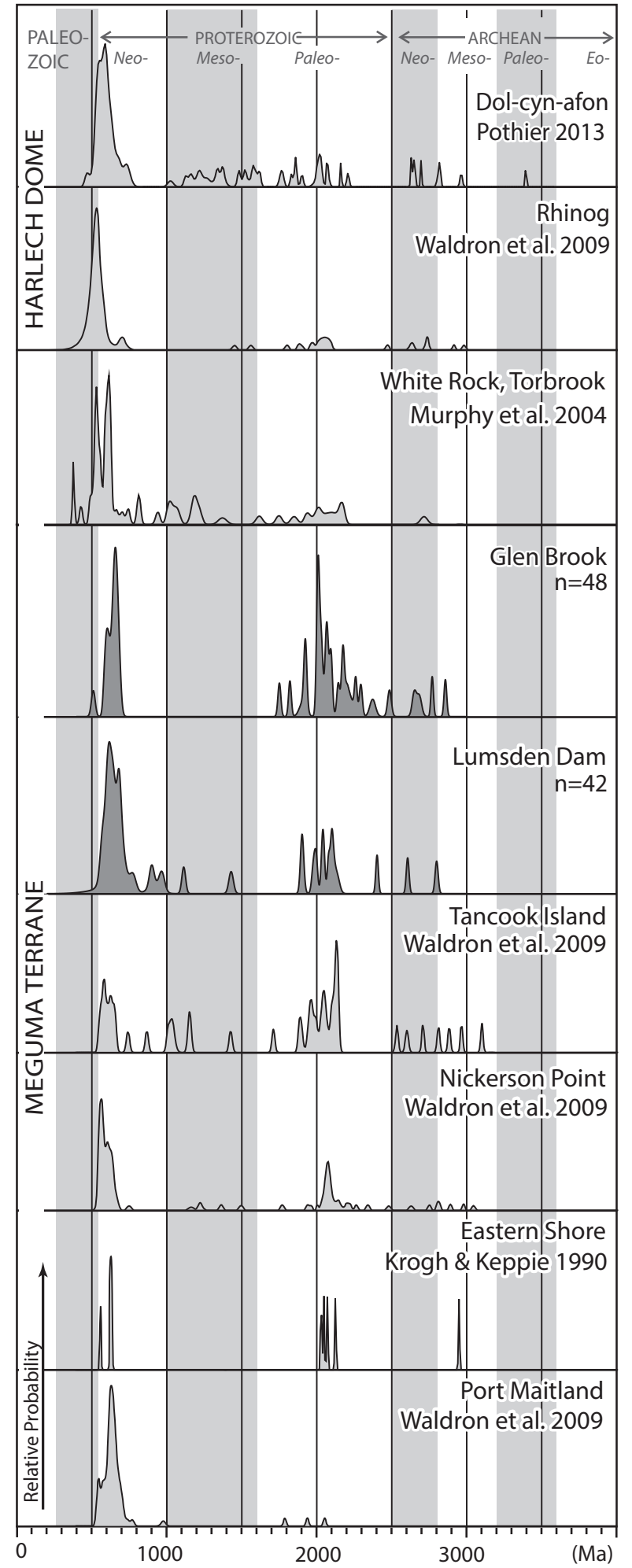

Figure 10. Probability density plot of detrital zircon data from the upper Halifax Group, compared with results from elsewhere in the Meguma terrane and the Harlech Dome region in North Wales after Krogh and Keppie (1990), Murphy et al. (2004a), Waldron et al. (2009), and Waldron et al. (2011). Calculations and plotting carried out with Isoplot 3.0 (Ludwig 2003). Complete analytical results and additional plots are shown in Appendices A and B.

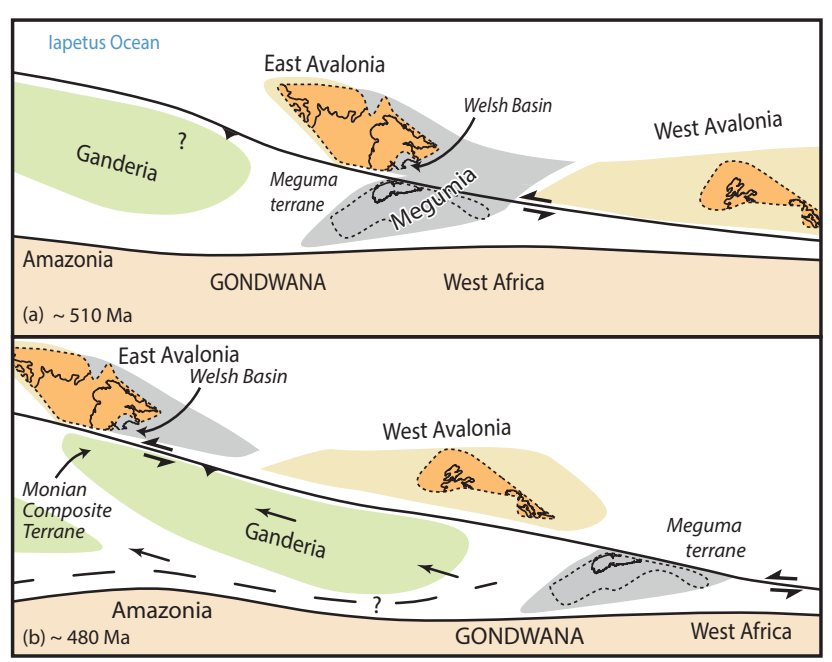

Figure 11. Possible paleogeographic reconstruction of the Gondwanan margin in (a) the Cambrian and (b) Early Ordovician, showing inferred relative displacement of Welsh basin and Meguma terrane. Dashed line in (b) schematically represents possible opening of Rheic Ocean between peri-Gondwanan terranes and Gondwana.

al. 2012).

\section{U-PB DETRITAL ZIRCON DATING}

\section{Wolfville area}

Sample NB027A for detrital zircon analysis was collected from the Lower Ordovician Lumsden Dam Formation in the overflow channel at Lumsden Dam [20T 0389877 4986952] (Fig. 1b, 2), approximately $20 \mathrm{~m}$ down-section from the Rhabdinoporas flabelliformus graptolite locality (shown at $162 \mathrm{~m}$ in Fig. 7). The sample was collected from a medium grey bed, $8 \mathrm{~cm}$ thick, of coarse siltstone. Petrographically, the sample is subarkosic wacke with subrounded grains. The rock has a primary fabric defined by the alignment of detrital mica grains and weak cleavage is detectable.

The sample was crushed using a jaw crusher and disk mill, and then passed over a Wilfley table to isolate the heavy grain fraction. Franz and heavy liquid separation were used to isolate the zircons. A random selection of zircons was mounted and imaged by electron backscatter using a scanning electron microscope. They were dated using U-Pb laser ablation multicollector inductively coupled plasma mass spectrometry (LA-MC-ICP-MS) with a NuPlasma instrument and UP213 laser ablation system from New Wave Research. Analytical protocol and data reduction were a modification of the procedure outlined in Simonetti et al. (2005). A $30 \mu \mathrm{m}$ spot size was used except when elevated ${ }^{206} \mathrm{~Pb} \mathrm{cps}$ tripped the ion counter. When this occurred, if possible the grains were reanalyzed with a $20 \mu \mathrm{m}$ spot size.

Two standards were used to normalize the grain ages. Standard LH94-15 with a U-Pb age of $1830 \pm 1 \mathrm{Ma}$ is a ho- 
mogeneous calc-alkaline enderbite (Simonetti et al. 2005; Ashton et al. 1999). Standard GJ-1 with a U-Pb age of 609 Ma is believed to have come from an East African pegmatite (Jackson et al. 2004; Elhlou et al. 2006). LH94-15 was used for all grains with uncorrected ${ }^{207} \mathrm{~Pb} /{ }^{206} \mathrm{~Pb}$ ratios greater than 0.0658 , corresponding to $\mathrm{a}^{207} \mathrm{~Pb} /{ }^{206} \mathrm{~Pb}$ age of $800 \mathrm{Ma}$. GJ-1 was used for all grains with uncorrected ${ }^{207} \mathrm{~Pb} /{ }^{206} \mathrm{~Pb}$ ratios less than this value.

Minor amounts of $\mathrm{Hg}$ present in the argon gas supply led to slightly elevated background counts at atomic mass 204, which therefore would have yielded invalid ages if treated as common lead. Therefore, ages were not common-lead corrected unless levels of ${ }^{204} \mathrm{~Pb}$ were higher than background levels (when counts per second of mass 204 were greater than 250).

One hundred and thirty-five grains were analyzed from the sample; however, 37 analyses were discarded due to low ${ }^{206} \mathrm{~Pb}$ counts per second (less than 10,000), high discordance, or very low ${ }^{238} \mathrm{U}$ contents suggesting a substantial non-zircon component to the grain. Of the remaining 111 analyses, only 42 recorded ages that were between -10 and $10 \%$ discordant. For grains with ${ }^{207} \mathrm{~Pb} /{ }^{206} \mathrm{~Pb}$ ages older than $800 \mathrm{Ma}$ the ${ }^{207} \mathrm{~Pb} /{ }^{206} \mathrm{~Pb}$ age is reported, as it typically shows higher analytical precision. For younger grains the ${ }^{206} \mathrm{~Pb} /{ }^{238} \mathrm{U}$ age, normally more precise, is reported. The distribution of ages is shown in Figure 10. Full analytical results are reported in Appendices A and B.

The detrital zircon results for the Lumsden Dam Formation (Fig. 10 and Appendix A) show a prominent Neoproterozoic peak centered at $612 \mathrm{Ma}$, defined by a cluster of ages (24 analyses) ranging from 556 to $796 \mathrm{Ma}$ (Fig. 10). This cluster is separated by a gap from an early Neoproterozoic grain group (3 analyses, 899 to $966 \mathrm{Ma}$ ). Two grains are of Mesoproterozoic age (1112 \pm 25 and $1429 \pm 30 \mathrm{Ma})$ and a significant Paleoproterozoic grain population with a cluster ( 9 analyses) ranges in age from $\sim 1900$ to $2140 \mathrm{Ma}$. The sample also contains one older Paleoproterozoic grain and two Archean grains with ages $2405 \pm 17,2610 \pm 19$ and $2803 \pm 20 \mathrm{Ma}$.

Young grains were generally euhedral to subhedral, and many exhibited oscillatory zoning. Old grains were generally sub-rounded to rounded and showed more homogeneous internal compositions with only weak zoning. Other features present in the grain population included core-rim structures, inclusions and fractures. These features typically were correlated with discordant ages.

\section{Eastern Nova Scotia}

Additional samples were collected in the Bluestone Quarry Formation, but failed to yield sufficient zircon grains on crushing and separation for worthwhile analysis. Therefore, to supplement the Lumsden Dam sample, and to represent equivalent strata lying unequivocally southeast of the CPSZ, we present here an older data set, previously unpublished, from the laterally equivalent Glen Brook For- mation (Fig. 2). This sample (LR080B, Fig. 1) was collected at a small quarry on Benvie Road [20T 498149 4997829] in Halifax Regional Municipality, from a bed of laminated siltstone approximately $15 \mathrm{~cm}$ thick. Zircons were extracted using the same methods as the sample from the Lumsden Dam Formation. One hundred and ten grains were analysed but, as for the Lumsden Dam sample, initial processing of the data produced many discordant results. This was probably due to the small grain size, which meant the ablated regions included zircon with variable isotopic age. Also, these analyses were subject to unusually large fluctuations in the signal at mass 204, leading to inappropriately large common- $\mathrm{Pb}$ corrections. On re-examination of the results, it proved possible to avoid some of the discordant results by excluding aberrant signals at the beginning or end of the ablation sequences, and by not attempting to apply the common- $\mathrm{Pb}$ correction; this probably resulted in the exclusion of a few analyses that contained significant common- $\mathrm{Pb}$, but was more than compensated by additional concordant results from grains with little common- $\mathrm{Pb}$. The reprocessed analyses contain sufficient concordant results (46 analyses) for comparison with the Lumsden Dam sample. Complete analytical results are provided in Appendix B.

The resulting distribution shows many similarities with the Lumsden Dam results, but some differences. A single grain at $511 \pm 25 \mathrm{Ma}$, within error of the inferred depositional age, has no counterpart in the Lumsden Dam sample. A Neoproterozoic cluster of 15 grains ranges from $~ 585$ to $\sim 685 \mathrm{Ma}$. There are no Mesoproterozoic grains, but as in the case of the Lumsden Dam Formation a large Paleoproterozoic population (26 grains) is present. The range of this Paleoproterozoic population is wider ( 1750 to $2490 \mathrm{Ma}$ ) but the largest concentration of grains is between 2000 and $2100 \mathrm{Ma}$, as in the Lumsden Dam sample. A small Archean population of 4 grains also covers approximately the same span as in the Lumsden Dam Formation.

\section{DISCUSSION}

\section{Correlation}

The Bluestone Quarry, Glen Brook, Feltzen, Bear River, and Lumsden Dam formations have been correlated based on their lithological similarities and their stratigraphic position above the Cunard Formation and its lateral equivalents, the North Alton and Acacia Brook Formations (White 2010a). The units comprise interbedded sandstone and siltstone with medium to dark grey mudstone and slate. The majority of beds exhibit vertical sequences of sedimentary structures described in the Bouma sequence (Bouma 1962), typical of turbidites. They are dominantly low-energy turbidites that record Bouma divisions $\mathrm{Tb}-\mathrm{Te}$ and $\mathrm{Tc}-\mathrm{Te}$, and contain high-energy turbidites that record Bouma divisions $\mathrm{Ta}-\mathrm{e}$ and Ta,e. Given these similarities, there are also important differences between the Bluestone Quarry and Lumsden Dam formations in particular. The 
Bluestone Quarry Formation contains a higher proportion of high-energy turbidites (Point Pleasant Park member) than the Lumsden Dam Formation and the mass transport deposits in the Bluestone Quarry Formation (Chain Rock member) are not present in the Lumsden Dam Formation. This difference can be attributed to slightly different positions relative to the basin margin, either laterally, or basinward. The slightly coarser Bluestone Quarry Formation may have been more proximal than the Lumsden Dam Formation. This is consistent with paleocurrent data that suggest a northwestward (present-day coordinates) flow direction, with the source region to the SE and a deep basin to the NW (Schenk 1970; Waldron et al. 2015).

The Meguma Supergroup has been correlated with the Cambrian to Tremadocian succession in the Harlech Dome of North Wales (Waldron et al. 2011). Both regions record thick early Cambrian continentally derived sandstone turbidites, overlain by early to middle Cambrian alternating mud-rich and sand-rich units that are enriched in manganese. The manganiferous interval is characterized in all regions by a diverse assemblage of trace fossils, including locally abundant Teichichnus. Above, the succession consists of anoxic, organic-rich turbidites, shallowing upwards into paler, Tremadocian mudstone and siltstone of the Dolcyn-afon Formation. This unit has been correlated with the Bluestone Quarry and Lumsden Dam formations of the Meguma terrane (Waldron et al. 2011; White et al. 2012; Pothier et al. 2015) based on its age and stratigraphic position.

\section{Age}

The Lumsden Dam Formation contains the graptolite Rhabdinopora flabelliformis flabelliformis and an acritarch assemblage of Tremadocian age (White et al. 2012). No fossils have been discovered in the Bluestone Quarry Formation and attempts to extract detrital zircons were unsuccessful; hence there is still no direct evidence for its age. Its stratigraphic position above the Cunard Formation and the lithological similarities between it and the Lumsden Dam Formation suggests the Bluestone Quarry Formation was also deposited during the Tremadocian. However, it is possible that the top of the Cunard Formation (and laterally equivalent units) represents a diachronous surface.

\section{Depositional Environment}

Schenk (1983) suggested the Meguma succession was deposited along the continental embankment of a passive margin; however, whole-rock geochemical data have been interpreted to suggest deposition in an active continental margin and (or) an island arc setting, not a passive margin (White et al. 2006; White and Barr 2010). Waldron et al. (2009) proposed a rift or extensional environment that subsequently became inactive. This hypothesis helps to explain the upward transition from a relatively juvenile Avalonian and Pan-African source to an older more diverse source region. In the early stages of basin development the uplifted rift flanks would supply the only source of sediment; later thermal subsidence permitted for a more extensive source region including Proterozoic and Archean rocks. This trend is reflected in $\varepsilon_{\mathrm{Nd}}$ values that show a change from a restricted juvenile source to more diverse and isotopically evolved sources (Waldron et al. 2009). This general model also explains the rapid accumulation of the $\sim 13 \mathrm{~km}$ thick succession, and perhaps the differences in the stratigraphic succession on either side of the CPSZ (Waldron et al. 2009).

The Goldenville Group is interpreted to represent a submarine, deep-sea fan deposit formed by turbidity currents and other types of sediment gravity flow (e.g., Schenk 1971; Harris and Schenk 1976; Waldron and Jensen 1985). Manganese accumulation at the top of the Goldenville Group was interpreted by Waldron (1992) as reflecting the intersection of the base of an oxygen minimum zone, in which $\mathrm{Mn}$ (II) was soluble, with the sea floor. The depositional environment for the shaly Cunard Formation of the lower Halifax Group has generally been interpreted as the midor upper-fan region of a muddy deep-marine fan that prograded over the Goldenville Group (Schenk 1971; Stow et al. 1984). Waldron $(1987,1992)$ attributed the abundance of graphite and sulphide minerals in the Cunard Formation to anaerobic conditions in the water column. The Lumsden Dam and Bluestone Quarry formations record a succession of low to high-energy turbidite deposits, probably deposited under slightly more oxidizing conditions, supported by the presence of trace fossils in the Feltzen and Bear River formations, inferred to be laterally equivalent. The presence of a mass transport deposit in the Bluestone Quarry Formation (Waldron et al. 2015) indicates that this unit was likely deposited in a slope environment. The Elderkin Brook and Hellgate Falls formations, which overlie the Lumsden Dam Formation (Fig. 2) show an upward progression into a highly bioturbated facies with abundant trace fossils, that lacks turbiditic structures. This suggests a transition from a slope into an outer shelf environment by the late Tremadocian. These observations are consistent with those of Schenk (1997), who interpreted the upper formations of the Halifax Group to represent a shoaling succession deposited between the upper slope of a prodelta and a muddy outer shelf.

\section{Provenance and paleogeography}

The Meguma terrane resided along the northern margin of Gondwana during the Cambrian (e.g., Cocks and Torsvik 2002; Nance et al. 2008); however, its exact position, and whether it formed its own discrete terrane or was a part of West Avalonia, are still subjects of controversy. Schenk (1970, 1981, 1997) and Robinson et al. (1998) have suggested the succession represents a continental prism that formed off the northwestern African margin, while others (e.g., Landing 2004; Murphy et al. 2004a) believed that it 
formed on the margin of West Avalonia. Some would place the Meguma terrane adjacent to the Amazonian craton (e.g., Keppie 1977; Linnemann et al. 2012), and others closer to the West African craton (e.g., Schenk 1997; Waldron et al. 2009).

Geochronological analyses of detrital zircon grains in clastic sedimentary rocks offer important information about potential source regions for sedimentary basin fill. This method has been an essential tool in determining the paleogeographic positions of many peri-Gondwanan terranes. Several detrital zircon studies (e.g., Waldron et al. 2009; Barr et al. 2012) within the Meguma terrane, West Avalonia, and Ganderia have attempted to distinguish West African craton from Amazonian craton sources. The West African craton is characterized by Paleoproterozoic rocks (2.0 to $2.2 \mathrm{Ga}$ ) related to the Eburnean and Birimian orogens, and Archean rocks (Rocci et al. 1991; Lerouge et al. 2006). The Amazonian craton has Paleoproterozoic and Archean sources as well, but also has extensive Mesoproterozoioc crust including the Rio Negro belt (1.6 to $1.8 \mathrm{Ga}$ ) and the Rondonia-Sunsas belts (1.3 to $1.0 \mathrm{Ga}$ ) (Litherland et al. 1985; Rowley and Pindell 1989). Thus the lack of a Mesoproterozoic grain population (c. 800 to $1700 \mathrm{Ma}$ ) has been considered an indicator of West African rather than Amazonian provenance (e.g., Nance and Murphy 1996; Linnemann et al. 2004).

Several detrital zircon samples have been analyzed from the Goldenville and Rockville Notch groups (Krogh and Keppie 1990; Murphy et al. 2004b; Waldron et al. 2009) (Fig. 10). Units sampled low in the Goldenville Group show a restricted distribution with prominent late Neoproterozoic grain populations. A Neoproterozoic to early Cambrian peak is common to many peri-Gondwanan terranes including Avalonia (Barr et al. 2012) and Ganderia (Fyffe et al. 2009; Murphy et al. 2004b; Waldron et al. 2011) and reflects Avalonian / Pan-African events that occurred between c. 540 and $700 \mathrm{Ma}$ along the Gondwanan margin (Nance et al. 1991, 2008).

Samples from higher in the Goldenville Group contain a few Mesoproterozoic grains, a significant population of grains between 2.0 and $2.2 \mathrm{Ga}$, and a range of Archean grains. These ages were interpreted by Krogh and Keppie (1990) and Waldron et al. (2009) to indicate sources in West Africa. The detrital zircon samples collected from the Lumsden Dam and Glen Brook formations show very similar distributions to the sample from the Government Point Formation in the upper part of the Goldenville Group (Fig. 10). In addition to the late Neoproterozoic peak they also contain significant populations between 1.9 and 2.1 $\mathrm{Ga}$, as well as 2.6 to $2.8 \mathrm{Ga}$ Archean grains. Mesoproterozoic grains are scarce in the Lumsden Dam Formation and absent from the sample of the Glen Brook Formation. The West African source interpreted for the Goldenville Group (e.g., Waldron et al. 2009; Krogh and Keppie 1990) thus appears to have continued to supply detritus to the Meguma terrane into the Ordovician.

\section{Relationship to the Welsh basin}

The sedimentary rocks of the Meguma terrane have been correlated with those of the Harlech Dome in North Wales (Waldron et al. 2011), leading to the inclusion of both terranes in the domain Megumia. Both regions display thick early Cambrian (Cambrian Series 1-2) continentally derived sandstone turbidites, overlain by early to middle (Series 2-3) Cambrian alternating mud-rich and sand-rich units in which manganese is concentrated. Above, the successions both comprise anoxic, organic-rich turbidites of Furongian (Cambrian Series 4) age, shallowing upward into paler, Early Ordovician mudstone and siltstone that contain the graptolite Rhabdinopora flabelliformis flabelliformis. In the Harlech Dome, the Tremadocian is represented by the mudstone-rich Dol-cyn-afon Formation which has previously been compared to the Lumsden Dam Formation based on its age and fossil assemblage (Waldron et al. 2011; White et al. 2012).

By the late Tremadocian the stratigraphic similarity between the Welsh Basin and the Meguma terrane ends and their histories diverged. The Lumsden Dam Formation records slope conditions that transition into shelf sedimentation recorded in the Elderkin Brook and Hellgate Falls formations. This was followed by a period of non-deposition and/or erosion and then by deposition of the Silurian volcano-sedimentary succession of the Rockville Notch Group. In the Harlech Dome, the Dol-cyn-afon Formation is unconformably overlain by late Tremadocian volcanic rocks followed by Floian sandstones and back-arc volcanic rocks through to the Late Ordovician.

Detrital zircon samples collected from Cambrian rocks (Rhinog and Gamlan formations) in the Harlech Dome exhibit a similar distribution (Fig. 10) to the Cambrian rocks of the Goldenville Group indicating they too were likely sourced from the Pan-African - Avalonian orogen and the West African craton (Waldron et al. 2011; Pothier et al. 2014). In contrast, new results from the Dol-cyn-afon Formation (Pothier et al. 2014) exhibit a detrital zircon distribution interpreted to show input of sediment from the Monian Composite terrane (Fig. 1a) in North Wales, which has been correlated with Ganderia of Atlantic Canada (Collins and Buchan 2004).

The similarities between the Dol-cyn-afon Formation and Monian detrital zircon distributions indicate the juxtaposition of the Monian composite terrane with North Wales by the Tremadocian (Pothier et al. 2014) along the NE-SW striking Menai Strait Fault System, which represents a terrane boundary in North Wales (Gibbons 1987). The new observations presented here are consistent with the divergence in Ordovician histories between the two basins and suggest that, if the two basins were contiguous in the Cambrian period, they had parted by the Tremadocian.

Waldron et al. (2011) proposed two paleogeographic reconstructions that would allow the Meguma terrane and the Welsh Basin to be adjacent during the Cambrian. In 
these scenarios, a likely mechanism to accommodate their diverging Ordovician histories would be strike-slip movement; Neoproterozoic subduction and arc activity along the Gondwanan margin were succeeded by a more stable environment by the early Paleozoic, where sinistral transcurrent motion is thought to have been prevalent (Nance et al. 1991, 2008). The Menai Strait Fault System between the Monian composite terrane and Welsh basin, active between the early Cambrian and late Carboniferous, is interpreted to show sinistral transpression (Gibbons 1987; Gibbons and Horák 1990). If a continuation of this fault system were to pass through Megumia, left-lateral migration could have displaced the Welsh Basin from an original position next to the Meguma terrane and juxtaposed it with the Monian composite terrane along the Gondwana margin. Figure 11 shows a possible terrane configuration consistent with this hypothesis, based on the assumption that Megumia was located within a rift system between East and West Avalonia. This model is consistent with both the sinistral transpressional setting for the Menai Strait Fault System, with the likely initial position of Ganderia (e.g., Pollock et al. 2009; van Staal et al. 2012) along the Amazonian margin, and with substantial rotation of portions of Avalonia during later Paleozoic history as suggested by Vizan et al. (2003).

\section{CONCLUSIONS}

(1) The Lumsden Dam Formation and Bluestone Quarry Formation are defined as formal lithostratigraphic units within the Halifax Group.

(2) The Bluestone Quarry and Lumsden Dam formations represent slope-related environments.

(3) The detrital zircon results from the Lumsden Dam Formation and Glen Brook Formation (likely correlative with the Bluestone Quarry Formation) show similar results to the Government Point Formation in the upper part of the Goldenville Group.

(4) These age populations are consistent with a source region in the West African craton with possible minor input from the Amazonian craton.

(5) Although the age and depositional environment for the Lumsden Dam Formation and the Dol-cyn-afon Formation of the Harlech Dome are similar, their different detrital zircon age populations suggest that the histories of the basins had diverged by the Tremadocian.

(6) A possible explanation for the diversification in detrital zircon ages within the Harlech Dome succession, and the diverging histories of the Meguma terrane and North Wales, could be left-lateral relative movement parallel to the margin of Gondwana along a transpressional fault system that separated the once adjacent basins by the Floian.

\section{ACKNOWLEDGEMENTS}

C.E.White publishes with the permission of the Director of the Nova Scotia Department of Natural Resources. We are grateful to the Natural Sciences and Engineering Research Council for Discovery Grant (A8508) funding to J.W.F. Waldron, and to the University of Alberta for student support to H.D. Pothier. Maryam Dzulkefli and Morgan Snyder assisted in the field. Guangchen Chen provided technical support in the mass spectrometry laboratory and Heather Clough, Matthew Kliffer and Robert Dokken assisted with mineral separation. We are grateful to journal referees Les Fyffe and Rob Raeside for their insightful reviews, and to the journal editors for discussions about formal and informal nomenclature.

\section{REFERENCES}

Ashton, K.E., Heaman, L.M., Lewry, J.F., Hartlaub, R.P., and Shi, R. 1999. Age and origin of the Jan Lake Complex: a glimpse at the buried Archean craton of the Trans-Hudson Orogen. Canadian Journal of Earth Sciences, 36, pp. 185-208. http://dx.doi.org/10.1139/ e98-038

Barr, S.M., Hamilton, M.A., Samson, S.D., Satkoski, A.M., and White, C.E. 2012. Provenance variations in northern Appalachian Avalonia based on detrital zircon age patterns in Ediacaran and Cambrian sedimentary rocks, New Brunswick and Nova Scotia, Canada. Canadian Journal of Earth Sciences, 49, pp. 533-546. http:// dx.doi.org/10.1139/e11-070

Boggs, S., 2001. Principles of sedimentology and stratigraphy 3rd edition Prentice-Hall, Upper Saddle River, New Jersey, $726 \mathrm{p}$.

Bouma, A.H. 1962. Sedimentology of some Flysch Deposits. A Graphic Approach to Facies Interpretation Elsevier, Amsterdam 168 p.

Bouyx, E., Blaise, J., Brice, D., Degardin, J.M., Goujet, D., Gourvennec, R., Le Menn, J., Lardeux, H., Morzadec, P. and Paris, F. 1997. Biostratigraphie et paleobiogeographie du Siluro-Devonien de la zone de Meguma (Nouvelle-Écosse, Canada). Canadian Journal of Earth Sciences, 34, pp. 1295-1309. http://dx.doi.org/10.1139/ e17-103

Cardwell, D.H., Erwin, R.B., and Woodward, H.P. 1968. Geologic Map of West Virginia: West Virginia Geological and Economic Survey, Map 1, East Sheet, scale 1:250 000.

Clarke, D.B. and Halliday, A.N. 1980. Strontium isotope geology of the South Mountain batholith, Nova Scotia. Geochimica et Cosmochimica Acta, 44, pp. 1045-1058. http://dx.doi.org/10.1016/0016-7037(80)90058-7

Clarke, D.B., Halliday, A.N., and Hamilton, P.J. 1988. Neodymium and strontium isotopic constraints on the origin of the peraluminous granitoids of the South Mountain Batholith, Nova Scotia, Canada. Chemical Geology, 73, pp. 15-24. 
Cocks, L.R.M. and Torsvik, T.H. 2002. Earth geography from 500 to 400 million years ago: a faunal and palaeomagnetic review. Journal of the Geological Society, London, 159, pp. 631-644. http://dx.doi. org/10.1144/0016-764901-118

Collins, A.S. and Buchan, C. 2004. Provenance and age constraints of the South Stack Group, Anglesey, UK: U-Pb SIMS detrital zircon data. Journal of the Geological Society, London, 161, pp. 743-746. http://dx.doi. org/10.1144/0016-764904-036

Eberz, G.W., Clarke, D.B., Chatterjee, A.K., and Giles, P.S. 1991. Chemical and isotopic composition of the lower crust beneath the Meguma Lithotectonic Zone, Nova Scotia: Evidence from granulite facies xenoliths. Contributions to Mineralogy and Petrology, 109, pp. 69-88. http://dx.doi.org/10.1007/BF00687201

Elhlou, S., Belousova, E., Griffin, W.L., Pearson, N.J., and O'Reilly, S.Y. 2006. Trace element and isotopic composition of GJ-red zircon standard by laser ablation. Geochimica et Cosmochimica Acta, 70, pp. A158-A158. http://dx.doi.org/10.1016/j.gca.2006.06.1383

Fyffe, L.R., Barr, S.M., Johnson, S.C., McLeod, M.J., McNicoll, V.J., Valverde-Vaquero, P., van Staal, C.R., and White, C.E. 2009. Detrital zircon ages from Neoproterozoic and Early Paleozoic conglomerate and sandstone units of New Brunswick and coastal Maine: Implications for the tectonic evolution of Ganderia. Atlantic Geology, 45, pp. 110-144. http://dx.doi. org/10.4138/atlgeol.2009.006

Gibbons, W. 1987. Menai Strait fault system: An early Caledonian terrane boundary in north Wales. Geology, 15, pp. 744-747. http://dx.doi.org/10.1130/00917613(1987)15<744:MSFSAE>2.0.CO;2

Gibbons, W. and Horák, J. 1990. Contrasting metamorphic terranes in northwest Wales. Geological Society, London, Special Publications, 51, pp. 315-327. http:// dx.doi.org/10.1144/GSL.SP.1990.051.01.20

Gingras, M.K., Waldron, J.W.F., White, C.E., and Barr, S.M. 2011. The evolutionary significance of a Lower Cambrian trace-fossil assemblage from the Meguma terrane, Nova Scotia. Canadian Journal of Earth Sciences, 48, pp. 71-85. http://dx.doi.org/10.1139/E10-086

Greenough, J.D., Krogh, T.E., Kamo, S.L., Owen, J.V., and Ruffman, A. 1999. Precise U-Pb dating of Meguma basement xenoliths: new evidence for Avalonian underthrusting. Canadian Journal of Earth Sciences, 36, pp. 15-22. http://dx.doi.org/10.1139/e98-079

Harris, I.M. and Schenk P.E. 1976. The Meguma Group. Maritime Sediments, 11, pp. 25-46.

Hart, G.G. 2006. Andalusite in the South Mountain Batholith contact aureole, Halifax Nova Scotia: a tale of two isograds. Unpublished B.Sc. thesis, Dalhousie University, Halifax, Nova Scotia, 121 p.

Hibbard, J.P., van Staal, C.R., Rankin, D.W., and Williams, H. 2006.Lithotectonic map of the Appalachian orogen, Canada - United States of America. Geological Survey of Canada Map 02096A, scale 1:1 500000.

Horne, R.J. and Pelley, D. 2007. Geological transect of the Meguma terrane from Centre Musquodoboit to Tangier. In Mineral Resources Branch, Review of Activities 2006. Edited by D.R. MacDonald. Nova Scotia Department of Natural Resources, Report, ME 2007-1. pp. 71-89.

Jackson, S.E., Pearson, N.J., Griffin, L., and Belousova, E.A. 2004. The application of laser ablation-inductively coupled plasma-mass spectrometry to in situ U-Pb zircon geochronology, 211, pp. 47-69.

Jamieson, R.A., Tobey, N., and ERTH 3020. 2005. Contact metamorphism of the Halifax Formation on the southeastern margin of the Halifax Pluton, Halifax, Nova Scotia. GAC-MAC-CSPG-CSSS Joint Annual Meeting, Halifax, Nova Scotia, Abstract Volume, 30, p. 95.

Jamieson, R.A., Waldron, J.W.F., and White, C.E. 2011. Bluestone formation of the Halifax Group: metamorphosed slope and mass-transport deposits, Halifax Peninsula, Nova Scotia. Atlantic Geology, 47, pp. 24-25. Jamieson, R.A., Hart, G.G., Chapman, G.G., and Tobey, N.W. 2012. The contact aureole of the South Mountain Batholith in Halifax, Nova Scotia: geology, mineral assemblages, and isograds. Canadian Journal of Earth Sciences, 49, pp. 1280-1296. http://dx.doi.org/10.1139/ e2012-058

Keppie, J.D. 1977. Tectonics of Southern Nova Scotia. Nova Scotia Department of Mines Paper 77-1, 34 p.

Keppie, J.D. and Dallmeyer, R.D. 1987. Dating transcurrent terrane accretion: an example from the Meguma and Avalon Composite terranes in the Northern Appalachians. Tectonics, 6, pp. 831-847. http://dx.doi. org/10.1029/TC006i006p00831

Keppie, J.D. and Krogh, T.E. 1999. U-Pb Geochronology of Devonian Granites in the Meguma Terrane of Nova Scotia, Canada: Evidence for Hotspot Melting of a Neoproterozoic Source. The Journal of Geology, 107, pp. 555-568. http://dx.doi.org/10.1086/314369

Keppie, J.D. and Krogh, T.E. 2000. 440 Ma igneous activity in the Meguma Terrane, Nova Scotia, Canada: part of the Appalachian overstep sequence. American Journal of Science, 300, pp. 528-538. http://dx.doi.org/10.2475/ ajs.300.6.528

Keppie, J.D. and Muecke, G.K. 1979. Metamorphic Map of Nova Scotia. Nova Scotia Department of Mines and Energy, Map ME 1979-006, scale 1:2 000000.

Keppie, J.D., Dostal, J., Murphy, J.B., and Cousens, B.L. 1997. Palaeozoic withinplate volcanic rocks in Nova Scotia reinterpreted: isotopic constraints on magmatic source and palaeocontinental reconstructions. Geological Magazine, 134, pp. 425-447. http://dx.doi. org/10.1017/S001675689700719X

Klein, G.D. 1962. Triassic sedimentation, Maritime Provinces, Canada. Geological Society of America Bulletin. 73, pp. 1127-1146. http://dx.doi.org/10.1130/00167606(1962)73[1127:TSMPC]2.0.CO;2 
Krogh, T.E. and Keppie, J.D. 1990. Age of detrital zircon and titanite in the Meguma Group, southern Nova Scotia, Canada: Clues to the origin of the Meguma Terrane. Tectonophysics, 177, pp. 307-323. http://dx.doi. org/10.1016/0040-1951(90)90287-I

Landing, E. 2004. Precambrian-Cambrian boundary interval deposition and marginal platform of the Avalon microcontinent. Journal of Geodynamics, 37, pp. 411-435. http://dx.doi.org/10.1016/j.jog.2004.02.014

Lane, T.E. 1975. Stratigraphy of the White Rock Formation. Maritime Sediments, 11, pp. 87-106.

Lerouge, C., Cocheria, A., Toteu, S.F., Penaye, J., Milesi, J.P., Tchameni, R., Nsifa, E.N., Fanning, C.M., and Deloule, E. 2006. Shrimp U-Pb zircon age evidence for Paleoproterozoic sedimentation and 2.05Ga syntectonic plutonism in the Nyong Group, South-Western Cameroon: consequences for the Eburnean-Transamazonian belt of NE Brazil and Central Africa. Journal of African Earth Sciences, 44, pp. 413-427. http://dx.doi. org/10.1016/j.jafrearsci.2005.11.010

Linnemann, U., McNaughton, N.J., Romer, R.L., Gehmlich, M., Drost, K., and Tonk, C. 2004. West African provenance for Saxo-Thuringia (Bohemian Massif): Did Armorica ever leave pre-Pangean Gondwana? $\mathrm{U} / \mathrm{Pb}$-SHRIMP zircon evidence and the $\mathrm{Nd}$-isotopic record. International Journal of Earth Sciences, 93, pp. 683-705. http://dx.doi.org/10.1007/s00531-004-0413-8

Linnemann, U., Herbosch, A., Liegeois, J.P., Pin, C., Gartner, A., and Hofmann, M. 2012. The Cambrian to Devonian odyssey of the Brabant Massif within Avalonia: A review with new zircon ages, geochemistry, Sm-Nd isotopes, stratigraphy and palaeogeography. Earth-Science Reviews, 112, pp. 126-154. http://dx.doi. org/10.1016/j.earscirev.2012.02.007

Litherland, M., Klinck, B.A., O'Connor, E.A., and Pitfield, P.E.J. 1985. Andean-trending mobile belts in the Brazilian Shield. Nature, 314, pp. 345-348. http://dx.doi. org $/ 10.1038 / 314345 \mathrm{a} 0$

Ludwig, K.R. 2003. User's Manual for Isoplot 3.00. Berkeley Geochronology Center Special Publication, 4. $74 \mathrm{p}$.

MacDonald, L.A., Barr, S.M., White, C.E., and Ketchum, J.W.F. 2002. Petrology, age, and tectonic setting of the White Rock Formation, Meguma terrane, Nova Scotia: evidence for Silurian continental rifting. Canadian Journal of Earth Sciences, 39, pp. 259-277. http:// dx.doi.org/10.1139/e01-074

Martel, A.T. and McGregor, D.C. 1993. Stratigraphic significance of Upper Devonian and Lower Carboniferous miospores from the type area of the Horton Group, Nova Scotia. Canadian Journal of Earth Science. 30, pp. 1091-1098. http://dx.doi.org/10.1139/e93-092

Murphy, J.B., Fernandez-Suarez, J., Keppie, J.D., and Jeffries, T.E. 2004a. Contiguous rather than discrete Paleozoic histories for the Avalon and Meguma Terranes based on detrital zircon data. Geology, 32, pp. 585-588. http://dx.doi.org/10.1130/G20351.1
Murphy, J.B., Fernandez-Suarez, J., Jeffries, T.E., and Strachan, R.A. 2004b. U-Pb (LA-ICP-M.S.) dating of detrital zircons from Cambrian clastic rocks in Avalonia: erosion of a Neoproterozoic arc along the northern Gondwanan margin. Journal of the Geological Society, London, 161, pp. 243-254. http://dx.doi. org/10.1144/0016-764903-064

Nance, R.D. and Murphy, J.B. 1996. Basement isotopic signatures and Neoproterozoic paleogeography of Avalonian-Cadomian and related terranes in the CircumNorth Atlantic. In Avalonian and Related Peri-Gondwanan Terranes of the Circum-North Atlantic. Edited by R.D. Nance and M.D. Thompson. Geological Society of America, Special Papers, 304, pp. 333-346. http:// dx.doi.org/10.1130/0-8137-2304-3.333

Nance, R.D., Murphy, J.B., Strahan, R.A., D’Lemos, R.S., and Taylor, G.K. 1991. Late Preoterozoic tectonostratigraphic evolution of the Avalonian and Cadomian terranes. Precambrian Research, 53, pp. 41-78. http:// dx.doi.org/10.1016/0301-9268(91)90005-U

Nance, R.D., Murphy, J.B., Strachan, R.A., Keppie, D.J. Gutiérrez-Alonso, G., Fernández-Suárez, J., Quesada, C., Linnemann, U., D’lemos, R., and Pisarevsky, S.A. 2008. Neoproterozoic-early Palaeozoic tectonostratigraphy and palaeogeography of the peri-Gondwanan terranes: Amazonian v. West African connections. Geological Society, London, Special Publications, 297, pp. 345-383.

O'Brien, B.H. 1988. A Study of the Meguma Terrane in Lunenburg County, Nova Scotia. Geological Survey of Canada Open File, 1823, 139 p. http://dx.doi. org/10.4095/130496

Peng, S., Babcock, L.E., and Cooper, R.A. 2012. The Cambrian Period. In A Geologic Time Scale 2012. Edited by F.M. Gradstein, J.G. Ogg, M. Schmitz, and G. Ogg. Elsevier, Amsterdam, pp. 437-488. http://dx.doi. org/10.1016/B978-0-444-59425-9.00019-6

Pollock, J.C., Hibbard, J.P., and Sylvester, P.J. 2009. Early Ordovician rifting of Avalonia and birth of the Rheic Ocean: $\mathrm{U}-\mathrm{Pb}$ detrital zircon constraints from Newfoundland. Journal of the Geological Society, London, 166, pp. 501-515. http://dx.doi.org/10.1144/001676492008-088

Pothier, H.D. 2013. Cambrian-Ordovician successions and detrital zircon geochronology of North Wales and Nova Scotia: terrane interactions between Ganderia and Megumia. Unpublished M.Sc. thesis, University of Alberta, Edmonton, Alberta, 183 p.

Pothier, H. D., Waldron, J.W.F., Schofield, D.I., and Dufrane S.A. 2014. Peri-Gondwanan terrane interactions recorded in the Cambrian-Ordovician detrital zircon geochronology of North Wales. Gondwana Research, in press-corrected proof. http://dx.doi.org/10.1016/j. gr.2014.08.009

Pratt, B.R. and Waldron, J.W.F. 1991. A Middle Cambrian trilobite faunule from the Meguma Group of Nova 
Scotia. Canadian Journal of Earth Sciences, 28, pp. 1843-1853. http://dx.doi.org/10.1139/e91-164

Raeside, R.P. and Jamieson, R.A. 1992. Low-pressure metamorphism of the Meguma Terrane, Nova Scotia. Geological Association of Canada and Mineralogical Association of Canada Joint Annual Meeting, Field Trip C5, Guidebook, 25 p.

Robinson, P., Tucker, R.D., Bradley, D., Berry, H.N.V., and Osberg, P.H. 1998. Paleozoic orogens in New England, USA: Geologiska Föreningens Förhandlingar, 120, pp. 119-148.

Rocci, G., Bronner, G., and Deschamps, M. 1991. Crystalline basement of the West African Craton. In The West African Orogens and Circum-Atlantic Correlatives. Edited by R.D. Dallmeyer and J.P. Lecorche. Berlin, Springer, pp. 31-61. http://dx.doi.org/10.1007/978-3642-84153-8_3

Rowley, D.B. and Pindell, J.L. 1989. End Paleozoic-early Mesozoic western Pangean reconstruction and its implications for the distribution of Precambrian and Paleozoic rocks around Meso-America: Precambrian Research, 42, pp. 411-444. http://dx.doi. org/10.1016/0301-9268(89)90022-3

Schenk, P.E. 1970. Regional variation of the flysch-like Meguma Group (Lower Palaeozoic) of Nova Scotia, compared to recent sedimentation off the Scotian shelf. Geological Association of Canada, Special Paper 7, 127-53.

Schenk, P.E. 1971. Southeastern Atlantic Canada, northwestern Africa, and continental drift. Canadian Journal of Earth Sciences, 8, pp. 1218-1251. http://dx.doi. org/10.1139/e71-113

Schenk, P.E. 1981. The Meguma zone of Nova Scotia: a remnant of western Europe, South America or Africa? In Geology of North Atlantic borderlands. Edited by J.M Kerr, A.J. Ferguson, and L.C. Machan. Canadian Society of Petroleum Geologists, Memoir 7, pp. 119-148.

Schenk, P.E. 1983. The Meguma terrane of Nova Scotia, Canada - An aid in trans-Atlantic correlation. In Regional trends in the geology of the Appalachian-Caledonian-Hercynian-Mauritanide orogen. Edited by P.E. Schenk. D. Reidel Publishing Co., pp. 121-130.

Schenk, P.E. 1995a. Meguma Zone. In Chapter 3 Geology of the Appalachian-Caledonian Orogen in Canada and Greenland. Edited by H. Williams. Geological Survey of Canada, Geology of Canada, 6, pp. 261-277.

Schenk, P.E. 1995b. Annapolis Belt. In Chapter 4 Geology of the Appalachian-Caledonian Orogen in Canada and Greenland. Edited by H. Williams. Geological Survey of Canada, Geology of Canada, 6, pp. 367-383.

Schenk, P.E. 1997. Sequence stratigraphy and provenance on Gondwana's margin: the Meguma Zone (Cambrian to Devonian) of Nova Scotia, Canada. Geological Society of America Bulletin, 109, pp. 395-409. http://dx.doi. org/10.1130/0016-7606(1997)109<0395:SSAPOG>2.3. $\mathrm{CO} ; 2$
Simonetti, A., Heaman, L.M., Hartlaub, R.P., Creaser, R.A., MacHattie, T.G., and Bohm, C. 2005. U-Pb zircon dating by laser ablation-MC-ICP-MS using a new multiple ion counting Faraday collector array. Journal of Analytical Atomic Spectrometry, 20, pp. 677-686. http:// dx.doi.org/10.1039/b504465k

Smitheringale, W.G. 1960. Geology of the Nictaux-Torbrook map-area, Annapolis and Kings counties, Nova Scotia. Geological Survey of Canada, Paper 60-13, 32 p. http://dx.doi.org/10.4095/108628

Smitheringale, W.G. 1973. Geology of parts of Digby, Bridgetown, and Gaspereau map-areas, Nova Scotia: Geological Survey of Canada Memoir 375, 78 p. http:// dx.doi.org/10.4095/109067

Stevenson, I.M. 1959. Shubenacadie and Kennetcook map areas, Colchester, Hants, and Halifax counties, Nova Scotia. Geological Survey of Canada Memoir 302, 88 p.

Stow, D.A.V., Alam, M., and Piper, D.J.W. 1984. Sedimentology of the Halifax Formation, Nova Scotia: Lower Paleozoic fine-grained turbitites. In Fine grained sediments: deep water processes and facies. Edited by D.J.W. Piper and D.A.V. Stow. Geological Society of London, Special Publication 15, pp. 127-144.

Taylor, F.C. 1965. Silurian stratigraphy and OrdovicianSilurian relationships in southwestern Nova Scotia. Geological Survey of Canada, Department of Mines and Technical Surveys, Paper 64-13, 25 p.

van Staal, C.R. 2007. Pre-Carboniferous tectonic evolution and metallogeny of the Canadian Appalachians. In Mineral Resources of Canada: A Synthesis of Major Deposit Types, Distinct Metallogeny, the Evolution of Geological Provinces, and Exploration Methods. Edited by W.D. Goodfellow. Geological Association of Canada, Mineral Deposits Division, Special Publication 5, pp. 793-818.

van Staal, C.R., Barr, S.B., and Murphy, J.B. 2012. Provenance and Tectonic Evolution of Ganderia: Constraints on the Evolution of the Iapetus and Rheic Oceans. Geology, 40, pp. 987-990. http://dx.doi.org/10.1130/ G33302.1

Vizan, H., Carney, J.N., Turner, P., Ixer, R.A., Tomasso, M., Mullen, R.P., and Clarke, P. 2003. Late Neoproterozoic to Early Palaeozoic palaeogeography of Avalonia: some palaeomagnetic constraints from Nuneaton, central England. Geological Magazine, 140, pp. 685-705. http://dx.doi.org/10.1017/S001675680300832X

Waldron, J.W.F. 1987. Sedimentology of the GoldenvilleHalifax transition in the Tancook Island area, South Shore, Nova Scotia. Geological Survey of Canada, Open File Report 1525., 49 p.

Waldron, J.W.F. 1992. The Goldenville-Halifax transition, Mahone Bay, Nova Scotia: relative sea-level rise in the Meguma source terrane. Canadian Journal of Earth Sciences, 29, pp. 1091-1105. http://dx.doi.org/10.1139/ e92-087 
Waldron, J.W.F. and Jensen, L.R. 1985. Sedimentology of the Goldenville Formation, Eastern Shore, Nova Scotia. Geological Survey of Canada, Paper, 85-15, 31 p.

Waldron, J.W.F., Piper, D.J.W., and Pe-Piper, G. 1989. Deformation of the Cape Chignecto Pluton, Cobequid Highlands, Nova Scotia: thrusting at the Meguma-Avalon boundary. Atlantic Geology, 25, pp. 51-62.

Waldron, J.W.F., White, C.E., Barr, S.M., Simonetti, A., and Heaman, L.M. 2009. Provenance of the Meguma terrane, Nova Scotia: rifted margin of early Paleozoic Gondwana. Canadian Journal of Earth Sciences, 46, pp. 1-9. http://dx.doi.org/10.1139/E09-004

Waldron, J.W.F., Schofield, D.I., White, C.E., and Barr, S.M. 2011. Cambrian successions of the Meguma Terrane, Nova Scotia, and Harlech Dome, North Wales: dispersed fragments of a peri-Gondwanan basin? Journal of the Geological Society, London, 168, pp. 83-98. http://dx.doi.org/10.1144/0016-76492010-068

Waldron, J.W.F., Jamieson R.A., Pothier H.D. and White C.E. 2015. Sedimentary and tectonic setting of a masstransport slope deposit in the Halifax Group, Halifax Peninsula, Nova Scotia. Atlantic Geology, 51

White, C.E. 2010a. Pre-Carboniferous bedrock geology of the Annapolis Valley area (NTS 21A/14, 15, and $16 ; 21 \mathrm{H} / 01$ and 02 ), southern Nova Scotia. In Mineral Resources Branch, Report of Activities 2009. Edited by D.R. MacDonald. Nova Scotia Department of Natural Resources, Report 2010-1, pp. 137-155.

White, C.E. 2010b. Stratigraphy of the Lower Paleozoic Goldenville and Halifax groups in the western part of southern Nova Scotia. Atlantic Geology, 46, pp. 136154. http://dx.doi.org/10.4138/atlgeol.2010.008
White, C.E. and Barr, S.M. 2010. Petrochemistry of the Lower Paleozoic Goldenville and Halifax groups, southwestern Nova Scotia, Canada: implications for stratigraphy, provenance, and tectonic setting of Meguma. In From Rodinia to Pangea: The Lithotectonic Record of the Appalachian Region. Geological Society of America Memoir 206, pp. 347-366.

White, C.E., Barr, S.M., and Toole, R.M. 2006. New insights on the origin of the Meguma Group in southwestern Nova Scotia, Canada. Nova Scotia Department of Natural Resources, Mineral Resource Branch, Open File Illustration, ME 2006-2.

White, C.E., Barr, S.M., Horne, R.J., and Hamilton, M.A. 2007. The Neoacadian orogeny in the Meguma terrane, Nova Scotia, Canada. In 42nd Annual Meeting Geological Society of America, Northeastern Section, March 12-14, Abstracts with Programs, 39, p. 69.

White, C.E., Bell, J.A., McLeish, D.F., Macdonald, M.A., Goodwin, T.A., and MacNeil, J.D. 2008. Geology of the Halifax Regional Municipality, Central Nova Scotia. In Mineral Resources Branch, Report of Activities 2007. Nova Scotia Department of Natural Resources, Report 2008-1, pp. 125-139.

White, C.E., Palacios, T., Jensen, S., and Barr, S.M. 2012. Cambrian-Ordovician acritarchs in the Meguma terrane, Nova Scotia, Canada: Resolution of early Paleozoic stratigraphy and implications for paleogeography. Geological Society of America Bulletin 124, pp. 17731792. http://dx.doi.org/10.1130/B30638.1

Woodman, J.E. 1904. Nomenclature of the gold-bearing metamorphic series of Nova Scotia. American Geologist, 33, pp. 363-370.

Editorial responsibility: Sandra M. Barr 


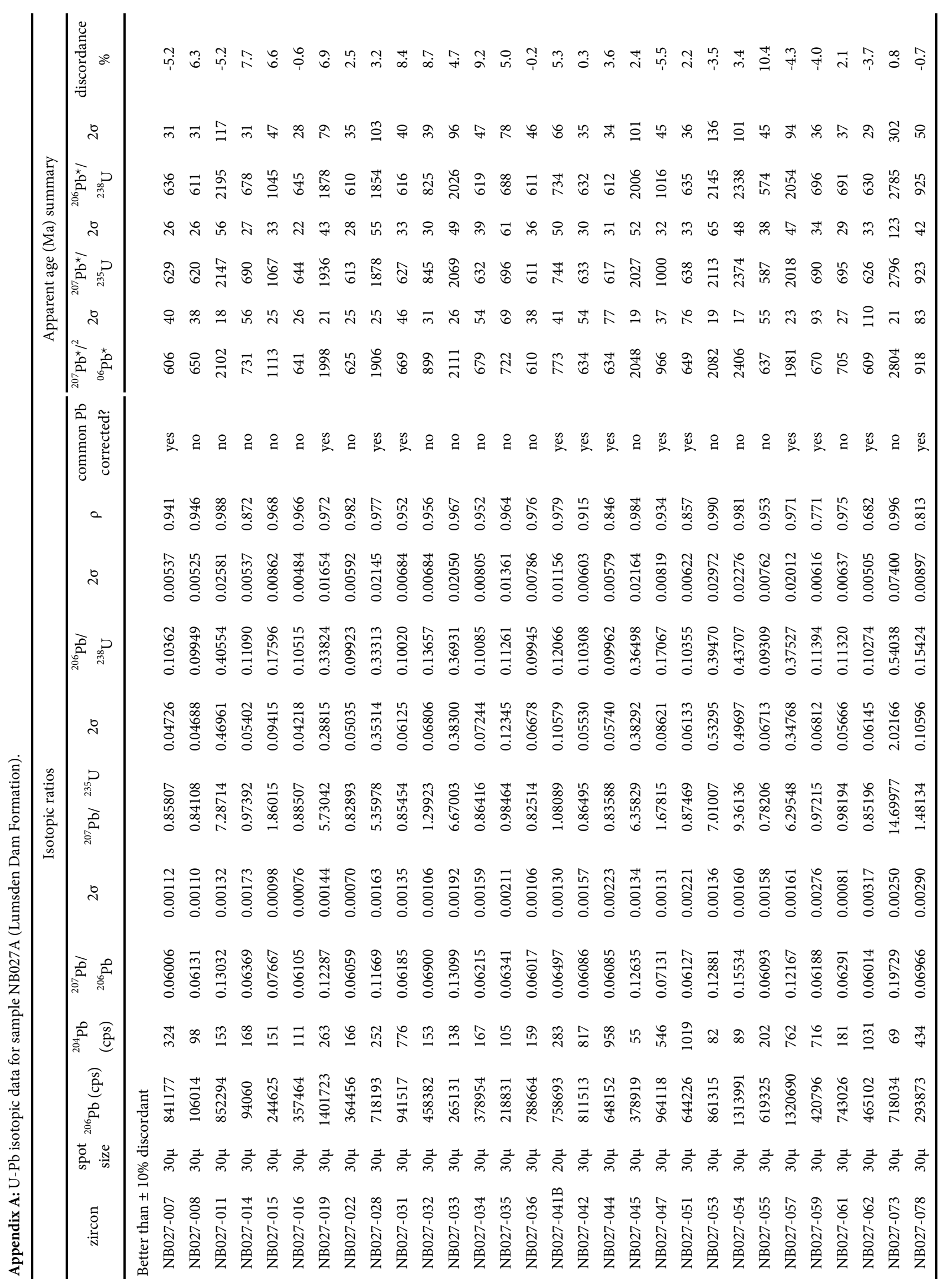




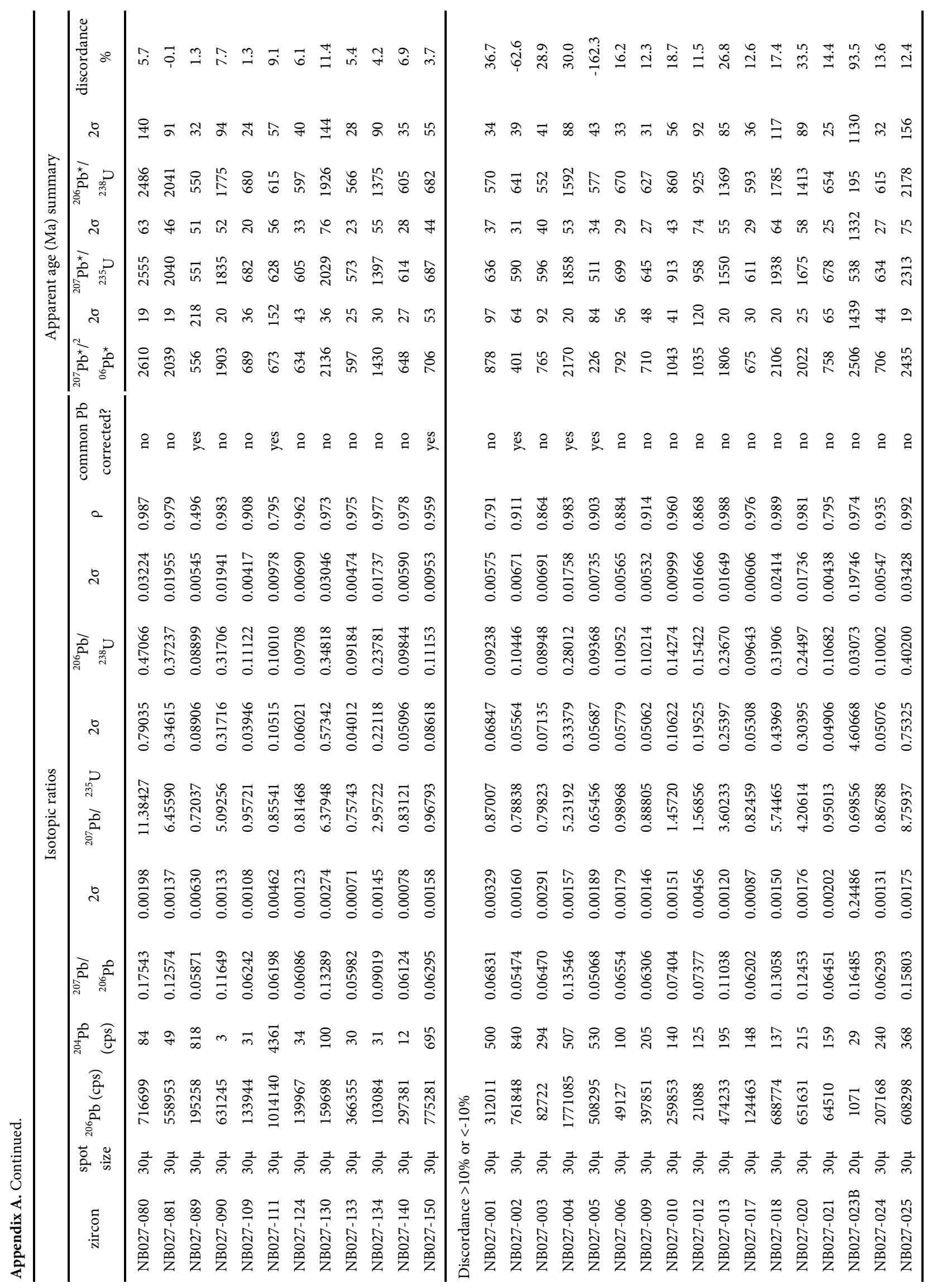




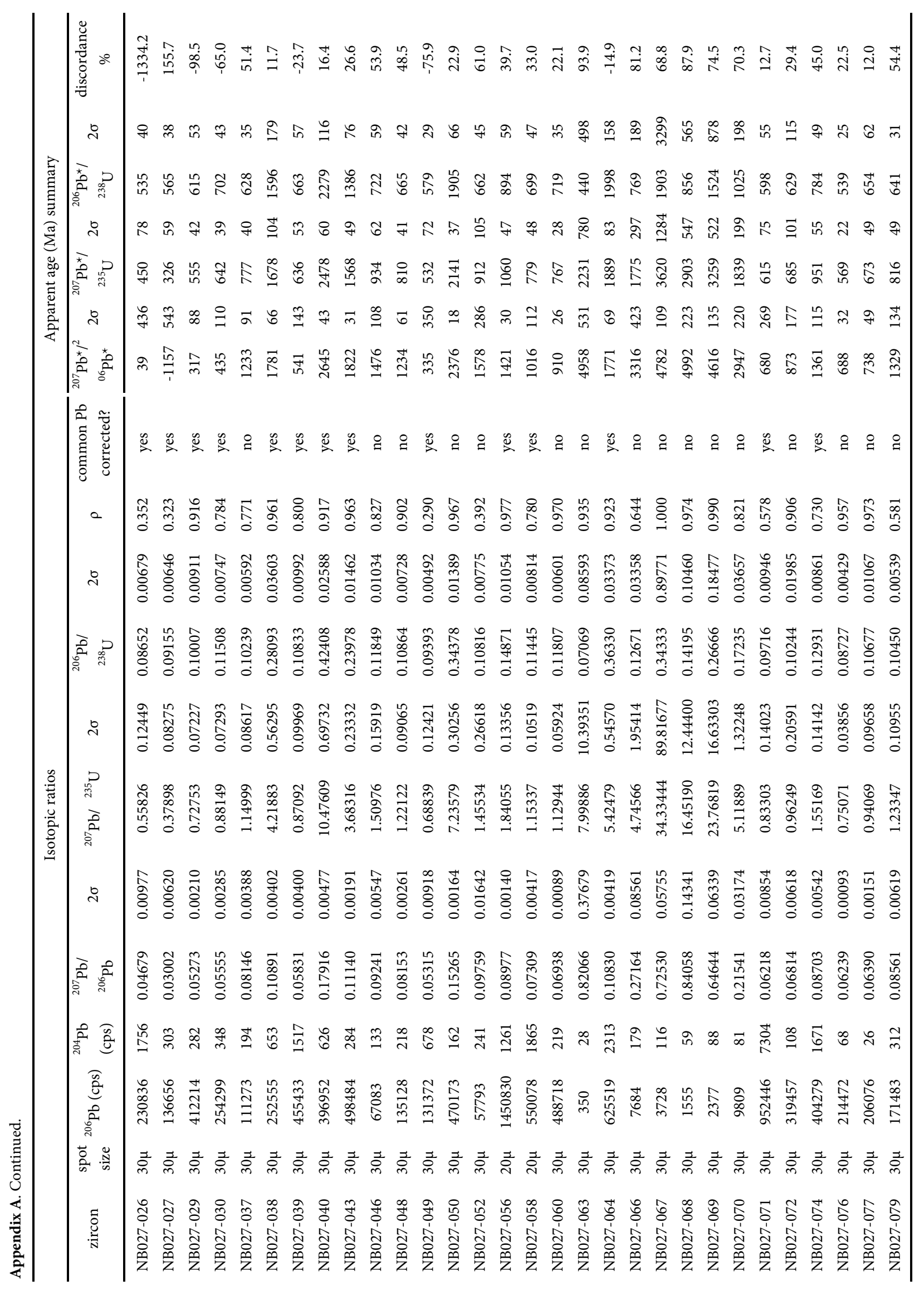




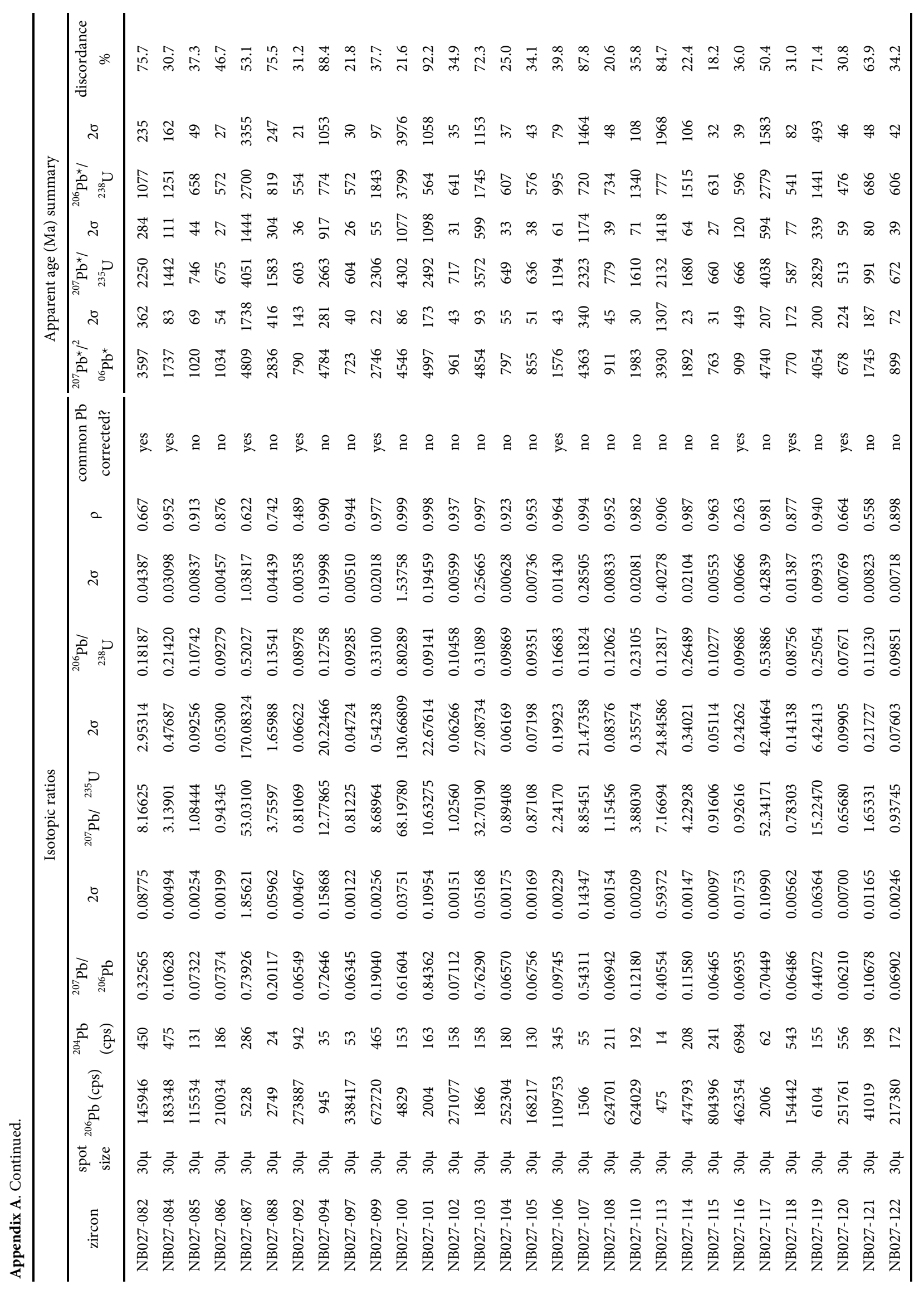




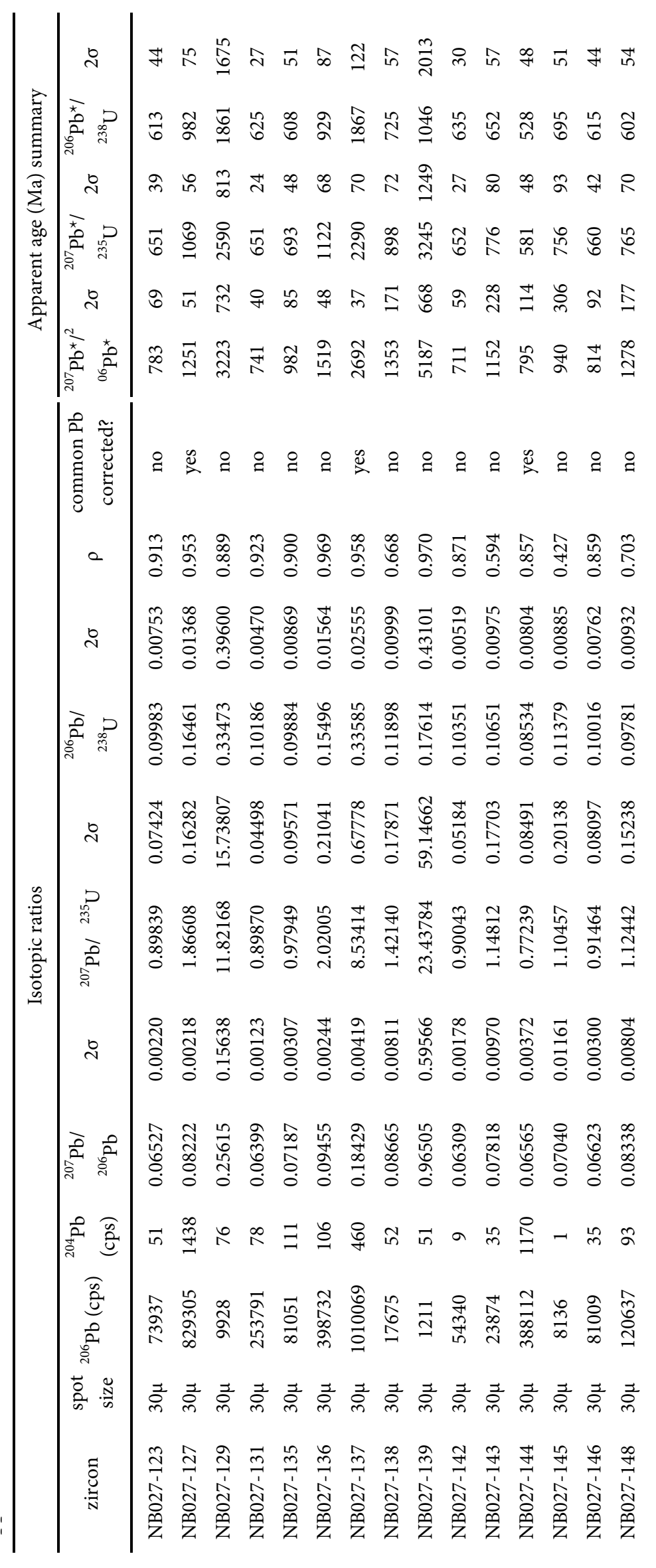



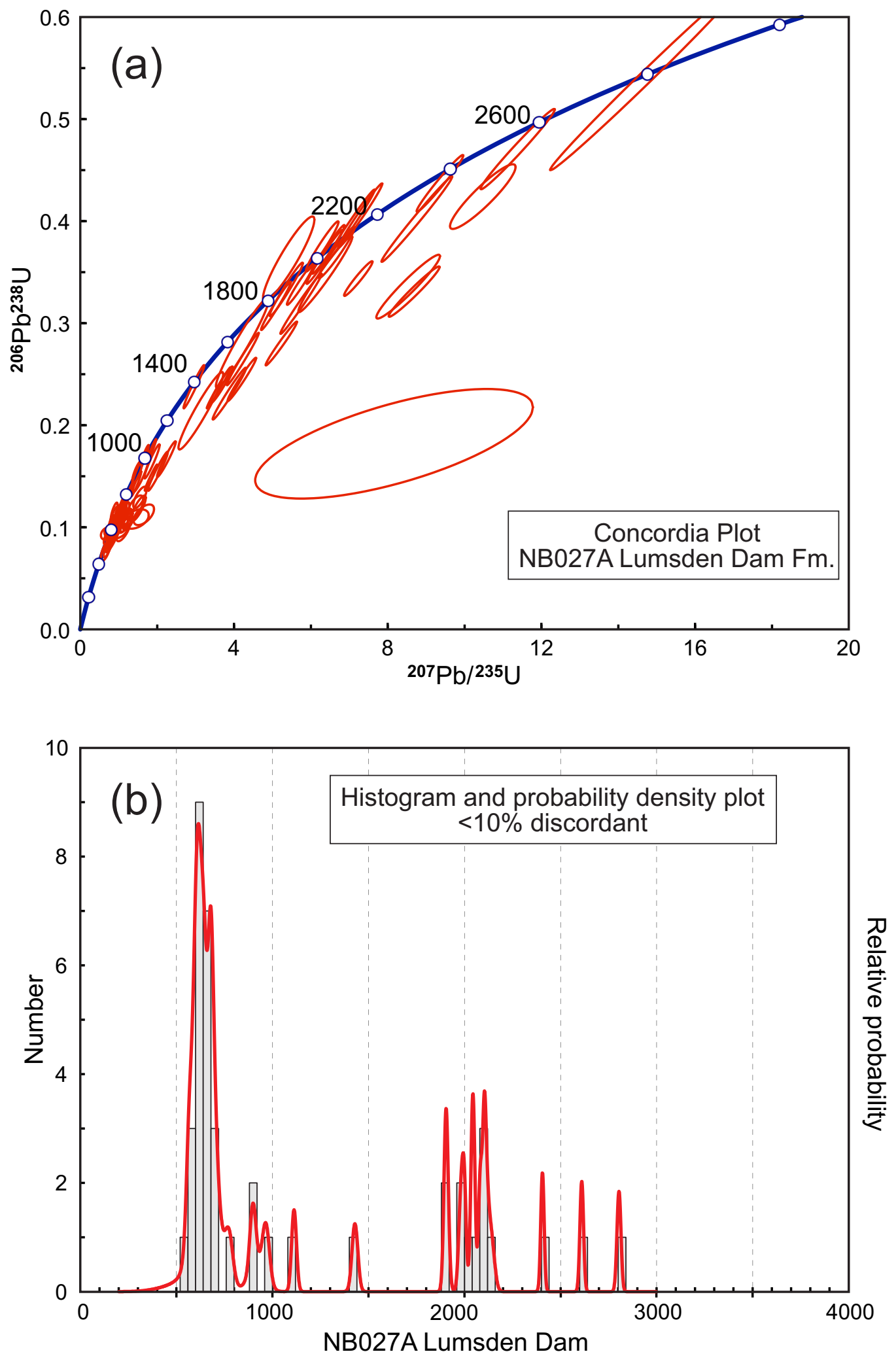

Figure A. U-Pb data for detrital zircons from the Lumsden Dam Formation. (a) U-Pb concordia plot. Errors are shown at the two sigma level. (b) Probability density curve and histograms of detrital zircon. Data shown are for $\mathrm{U}-\mathrm{Pb}$ analyses that are $<10 \%$ discordant: ${ }^{207} \mathrm{~Pb} /{ }^{206} \mathrm{~Pb}$ ages for analyses $>800 \mathrm{Ma}$, and ${ }^{206} \mathrm{~Pb} /{ }^{238} \mathrm{U}$ ages are analyses $<800 \mathrm{Ma}$. 


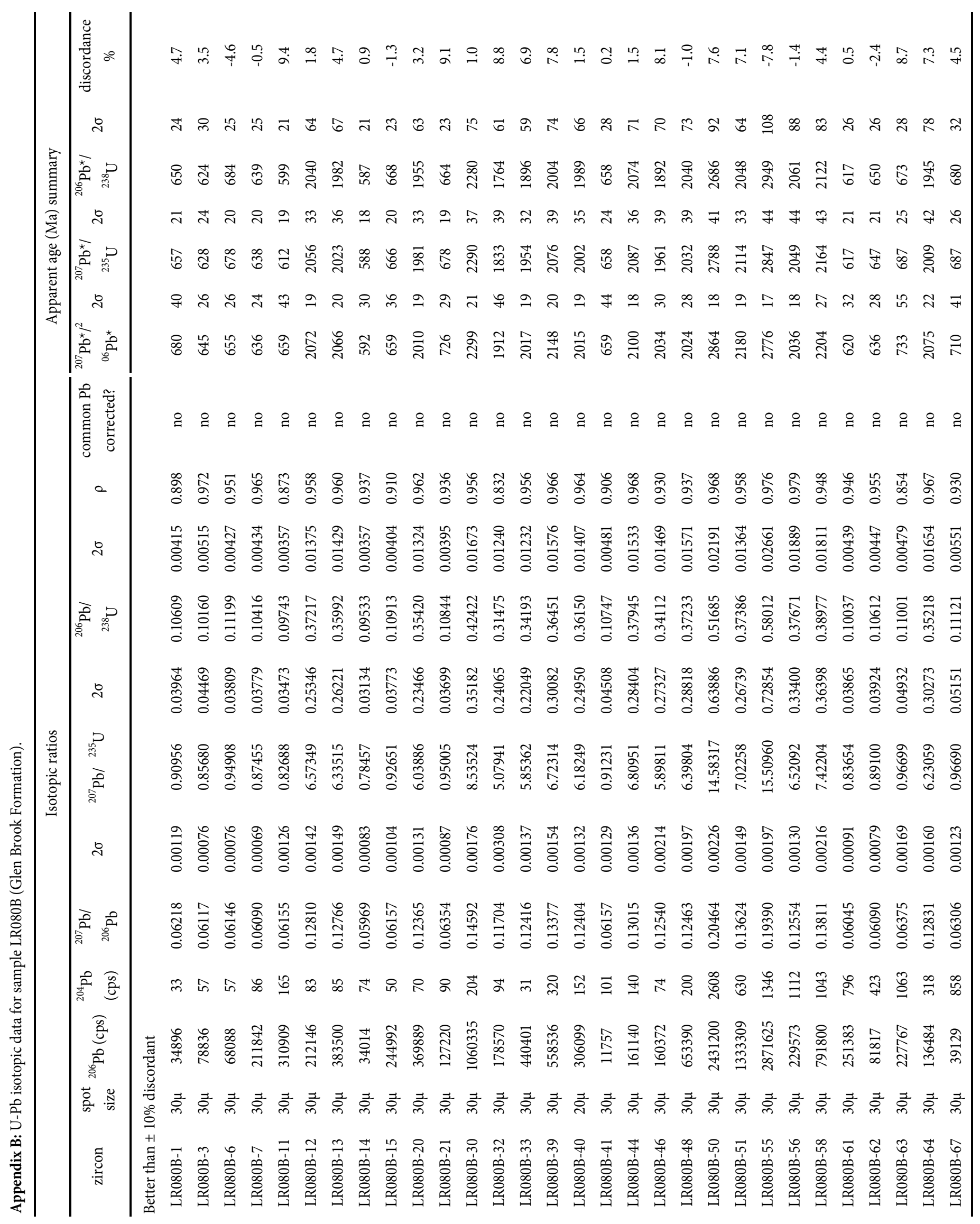




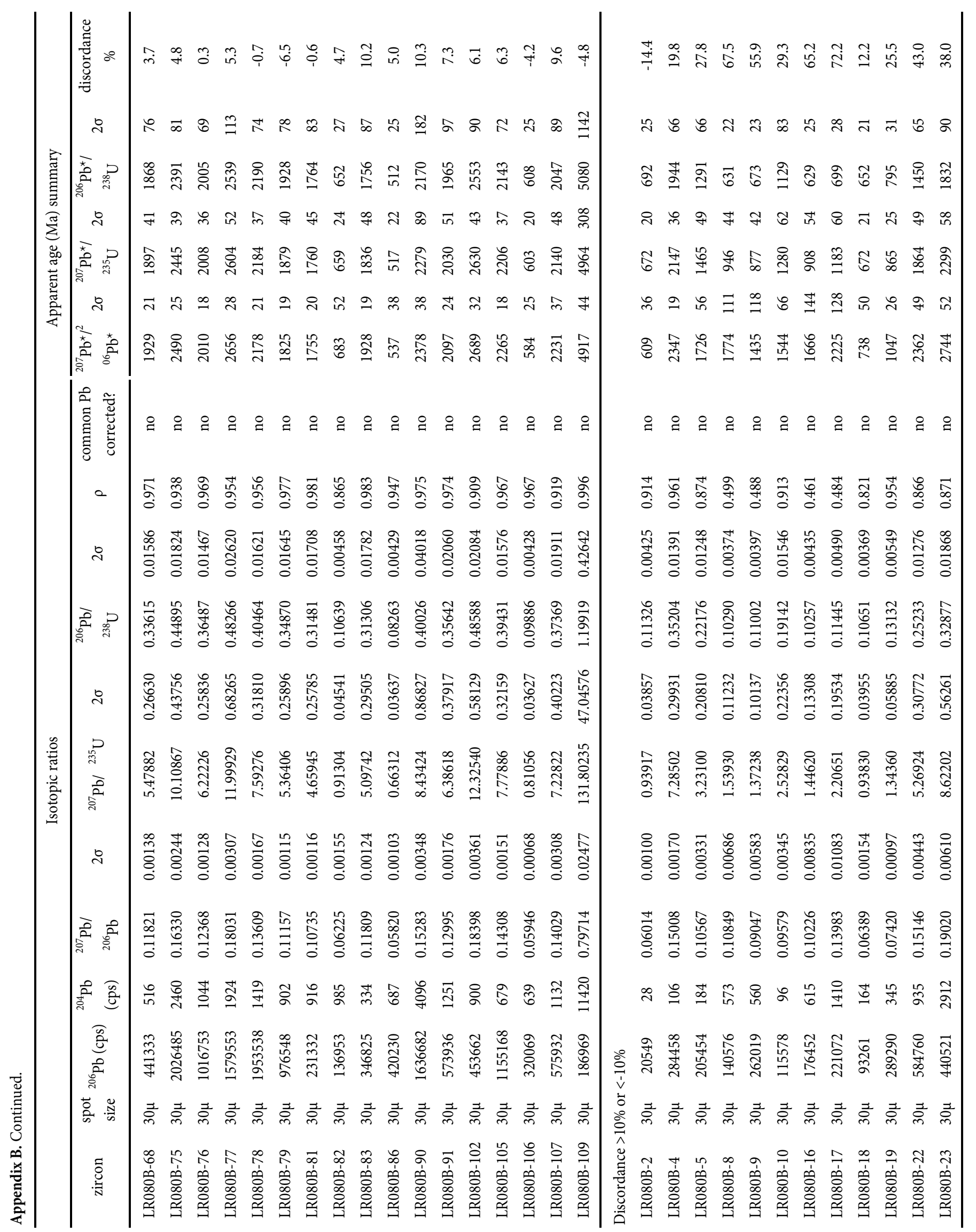




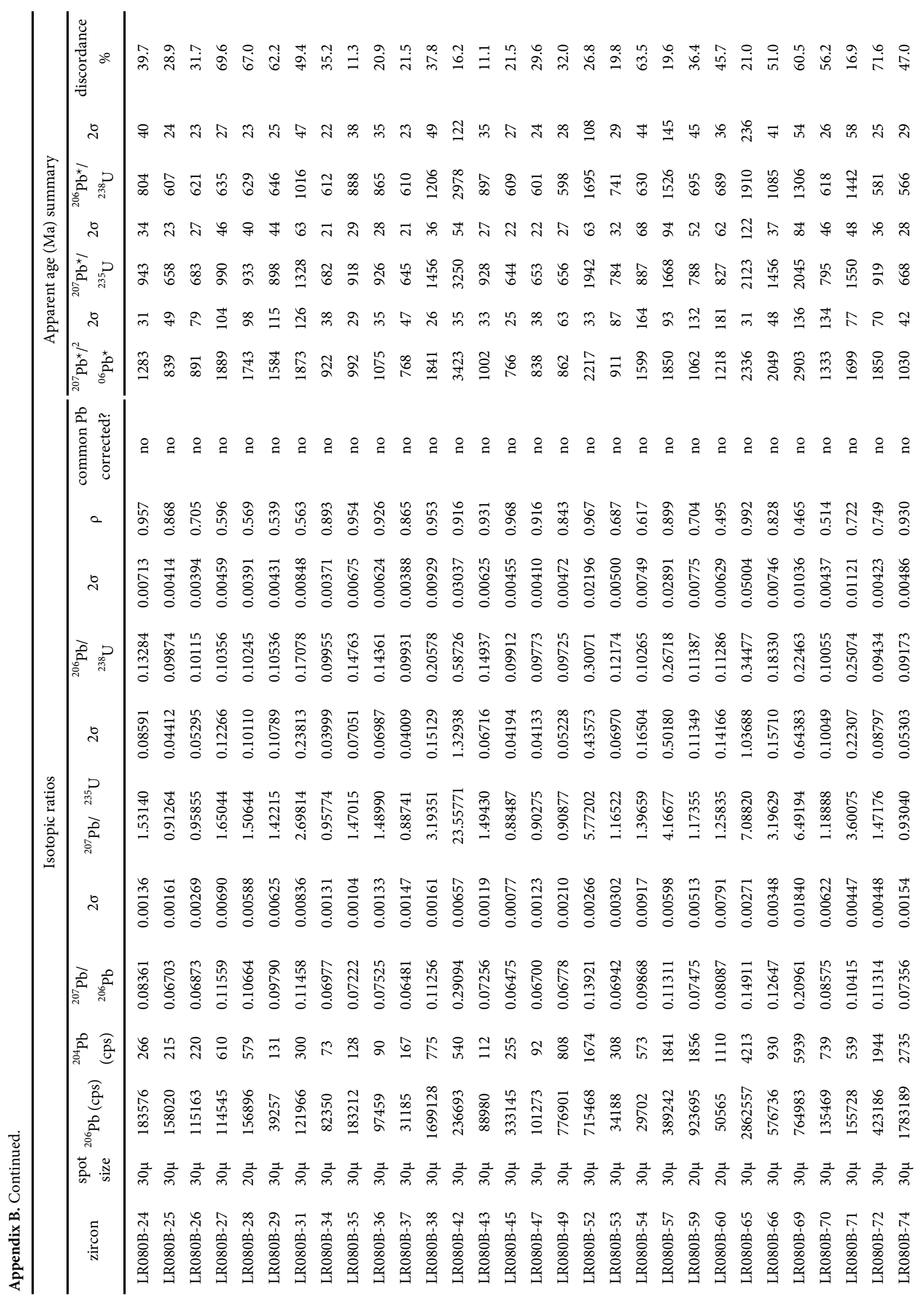




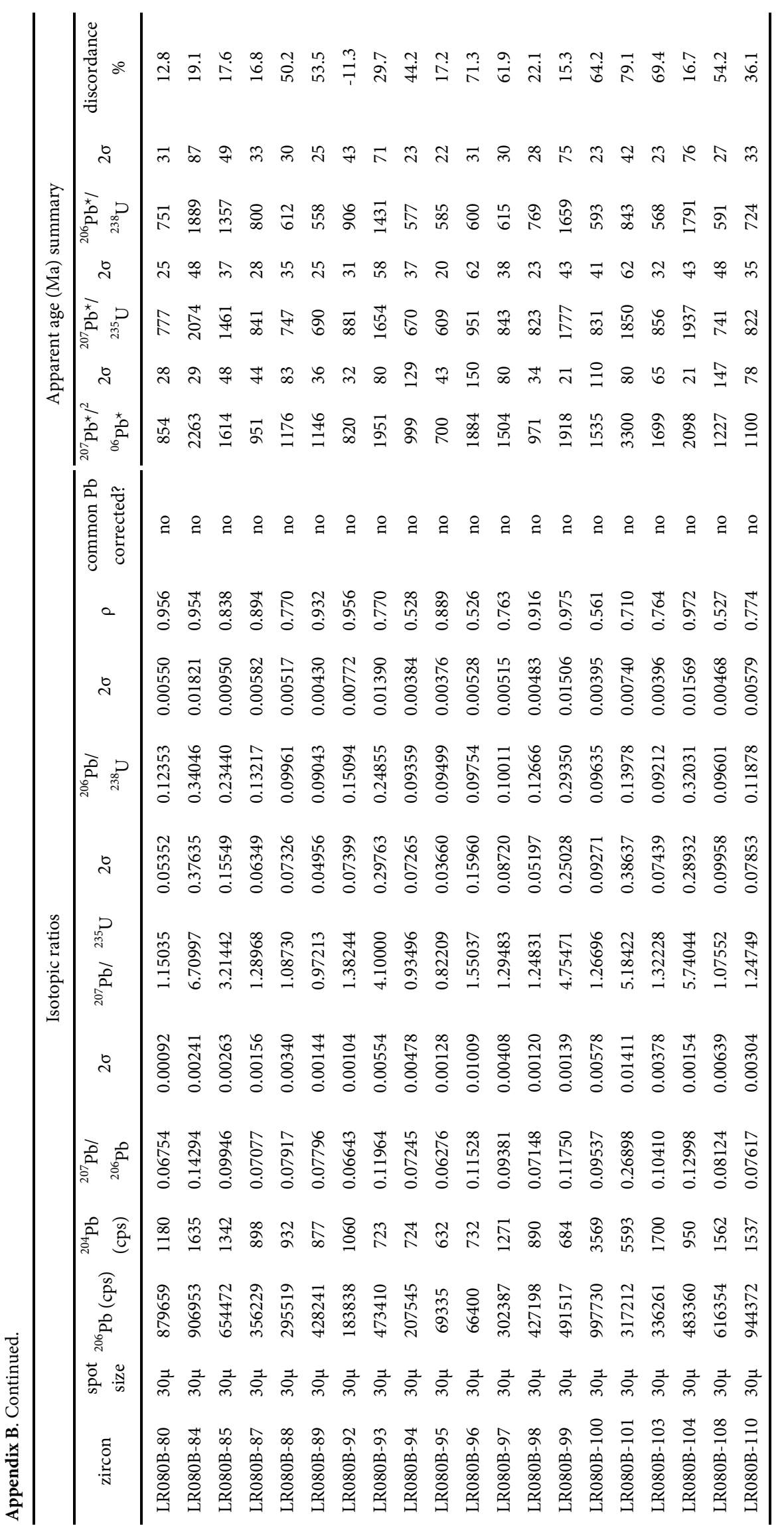



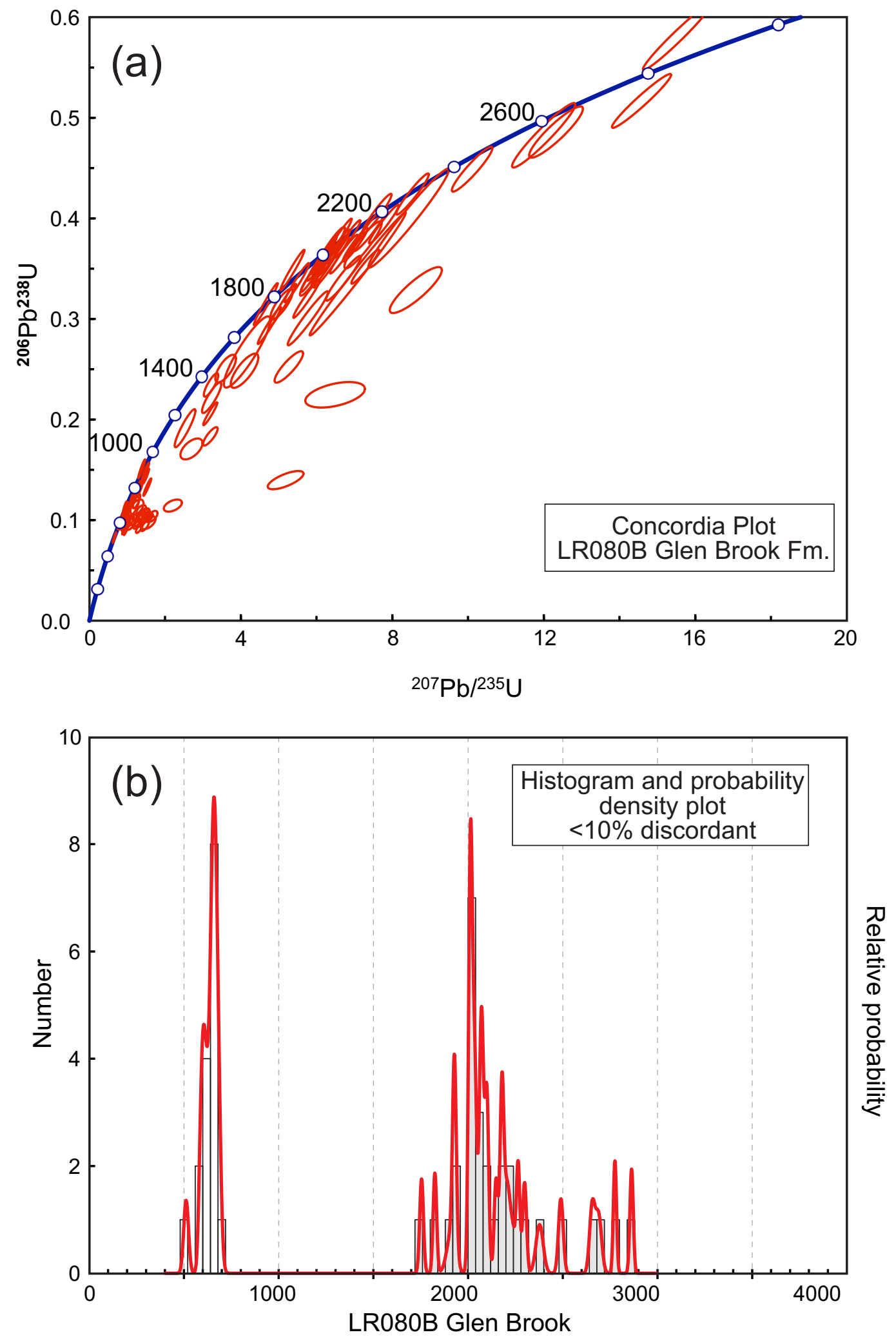

Figure B. U-Pb data for detrital zircons from the Glen Brook Formation. (a) U-Pb concordia plot. Errors are shown at the two sigma level. (b) Probability density curve and histograms of detrital zircon. Data shown are for $\mathrm{U}-\mathrm{Pb}$ analyses that are $<10 \%$ discordant: ${ }^{207} \mathrm{~Pb} /{ }^{206} \mathrm{~Pb}$ ages for analyses $>800 \mathrm{Ma}$, and ${ }^{206} \mathrm{~Pb} /{ }^{238} \mathrm{U}$ ages are analyses $<800 \mathrm{Ma}$. 